\title{
Intra- and Inter-specific Variation of Four Acetes Species (Crustacea: Decapoda: Sergestidae) Sampled along the West Coast of Peninsular Malaysia \\ (Variasi Intra- dan antara Spesies Empat Spesies Acetes (Crustacea: Decapoda: Sergestidae) disampel Sepanjang Pantai Barat Semenanjung Malaysia)
}

\author{
Boon Yee Wong, Taranjeet Kaur Awtar Singh, Gideon Khoo \& Han Kiat Alan OnG*
}

\begin{abstract}
The intra-and inter-specific variation of Acetes shrimps were evaluated based on samples collected from in-shore catches and off-shore trawling around the west coast of Peninsular Malaysia. Species captured were identified as Acetes indicus, A. serrulatus, A. japonicus and A. sibogae. A region of the mitochondrial cytochrome c oxidase subunit I (COI) gene comprising 552 base pairs (bp) was amplified from 159 Acetes specimens. The sequence alignment analysis generated phylogenetic trees which depicted the four major clades that were consistent with the species identified morphologically. These four species varied considerably for haplotype and nucleotide diversity, with A. indicus and A. serrulatus showing different demographic histories. Furthermore, the observation of two clades in the A. indicus and A. sibogae lineages, with relatively high levels of intraspecific divergence, suggests that cryptic diversity is possibly present in these two taxa. This study has contributed to the knowledge of the distribution patterns and molecular phylogenetics of four Acetes spp. in the Straits of Malacca.
\end{abstract}

Keywords: Acetes; COI gene; cryptic species; Peninsular Malaysia; phylogenetic analysis

\section{ABSTRAK}

Variasi intra- dan antara spesies Acetes dinilai berdasarkan sampel yang dikumpulkan daripada tangkapan di pantai dan tunda di luar pesisir pantai di sekitar pantai barat Semenanjung Malaysia. Spesies yang ditangkap dikenal pasti sebagai Acetes indicus, A. serrulatus, A. japonicus dan A. sibogae. Suatu kawasan gen sitokrom c oksidase mitokondria subunit I (COI) yang terdiri daripada 552 pasangan bes ( bp) telah teramplifikasi daripada 159 spesimen Acetes. Analisis penjajaran jujukan menghasilkan pokok filogenetik yang menggambarkan empat klad utama adalah tekal dengan spesies yang telah dikenal pasti secara morfologi. Empat spesies ini sangat berbeza daripada segi kepelbagaian haplotip dan nukleotid dengan A. indicus dan A. serrulatus menunjukkan sejarah demografi yang berbeza. Tambahan pula, pemerhatian titisan dalam dua klad A. indicus dan A. sibogae, dengan tahap perbezaan intraspesies yang agak tinggi, menunjukkan bahawa kepelbagaian krip mungkin ada dalam dua taksa ini. Kajian ini telah menyumbang kepada pengetahuan tentang pola taburan dan molekul filogenetik empat Acetes spp. di Selat Melaka.

Kata kunci: Acetes; analisis filogenetik; gen COI; Semenanjung Malaysia; spesies kriptik

\section{INTRODUCTION}

Acetes shrimps of the family Sergestidae (Decapoda) are small planktonic shrimps (10-40 mm in total length), which are locally known as 'Udang Geragau' or 'Udang Baring' (Omori 1978, 1975). Currently, seven out of 14 described Acetes species have been found within Malaysian coastal waters, namely Acetes indicus, A.japonicus, A. serrulatus, A. vulgaris, A. sibogae, A. intermedius and A. erythraeus (Amani et al. 2011a, 2011b, 2011c; Amin et al. 2011, 2010, 2009a, 2009b, 2009c, 2009d, 2008; Arshad et al. 2012, 2008, 2007; Longhurst 1970; Omori 1975, 1978; Pathansali 1966). Landings of Acetes species are confined mainly to the west coast of Peninsular Malaysia where $75 \%$ or more of the total landing occurs (DOF 2013). Acetes are known for their commercial importance in subsistence fisheries (Holthuis 1980; Omori 1978, 1975) and potential use as feed in agriculture and aquaculture (Deshmukh 1991; Job et al. 2006). These species also play important roles as both predators and prey in the food webs of coastal waters (Xiao \& Greenwood 1993).

Previous studies on Acetes spp. focused mainly on their population dynamics, distribution, morphology, reproductive biology, morphometrics and lifecycles (Amani et al. 2011a, 2011b, 2011c; Amin et al. 2011, 2010, 2009a, 2009b, 2009c, 2009d, 2008; Arshad et al. 2012, 2008, 2007; Wong 2013; Wong et al. 2015). Presently, little is known about their genetic diversity spanning the common fishing grounds along the west coast of Peninsular Malaysia. To conserve the existing resources of these highly exploited species for long-term sustainable yields, information on the genetic diversity of Acetes populations is crucial for the assessment and management of wild stocks (Allendorf \& Luikart 2006; Carvalho \& Hauser 1994; Thorpe et al. 2000; Ward 2000; Ward \& Grewe 1994). 
The identification of Acetes species is commonly based on the global identification keys by Omori (1975) as this identification system applies to a vast geographical coverage and is also able to differentiate males from females at different stages of their life cycles (Wong 2013; Wong et al. 2015). Conversely, species identification studies using the mitochondrial cytochrome $c$ oxidase subunit I (COI) gene have shown the usefulness of its sequence analysis in examining the phylogenetic and evolutionary relationships of decapod crustaceans such as penaeid shrimps (Baldwin et al. 1998), brachyuran crabs of the genus Cancer (Harrison \& Crespi 1999), snapping shrimp genus Alpheus (Williams et al.2001), Farfantepenaeus shrimps in Cuban waters (García-Machado et al . 2001), Western Pacific squat lobsters (Machordom \& Macpherson 2004), European crayfish genus Austropotamobius (Trontelj et al. 2005), freshwater glass shrimp Paratya australiensis in eastern Australia (Cook et al. 2006), giant tiger prawn Penaeus monodon in Thai waters (Khamnamtong et al. 2009), Melicertus kerathurus populations in the Mediterranean
Sea and eastern Atlantic Ocean (Pellerito et al. 2009), Western Mediterranean red shrimp Aristeus antennatus (Roldán et al. 2009) and Indo-West Pacific portunid crabs (Lai et al. 2010).

In this study, morphological identification based on the global identification keys of Omori (1975) and mtDNA COI sequence analyses were used to evaluate the genetic diversity and phylogenetic relationships among Acetes species in the west coast of Peninsular Malaysia.

\section{MATERIALS \& METHODS}

\section{SAMPLE COLLECTION AND IDENTIFICATION}

Acetes shrimps were sampled from inshore catches using push-nets and trawling activities at sea more than 5 nautical miles (nm) offshore along the west coast of Peninsular Malaysia (Figure 1), from August 2007 to October 2008. A global positioning system (GPS) was used to mark the

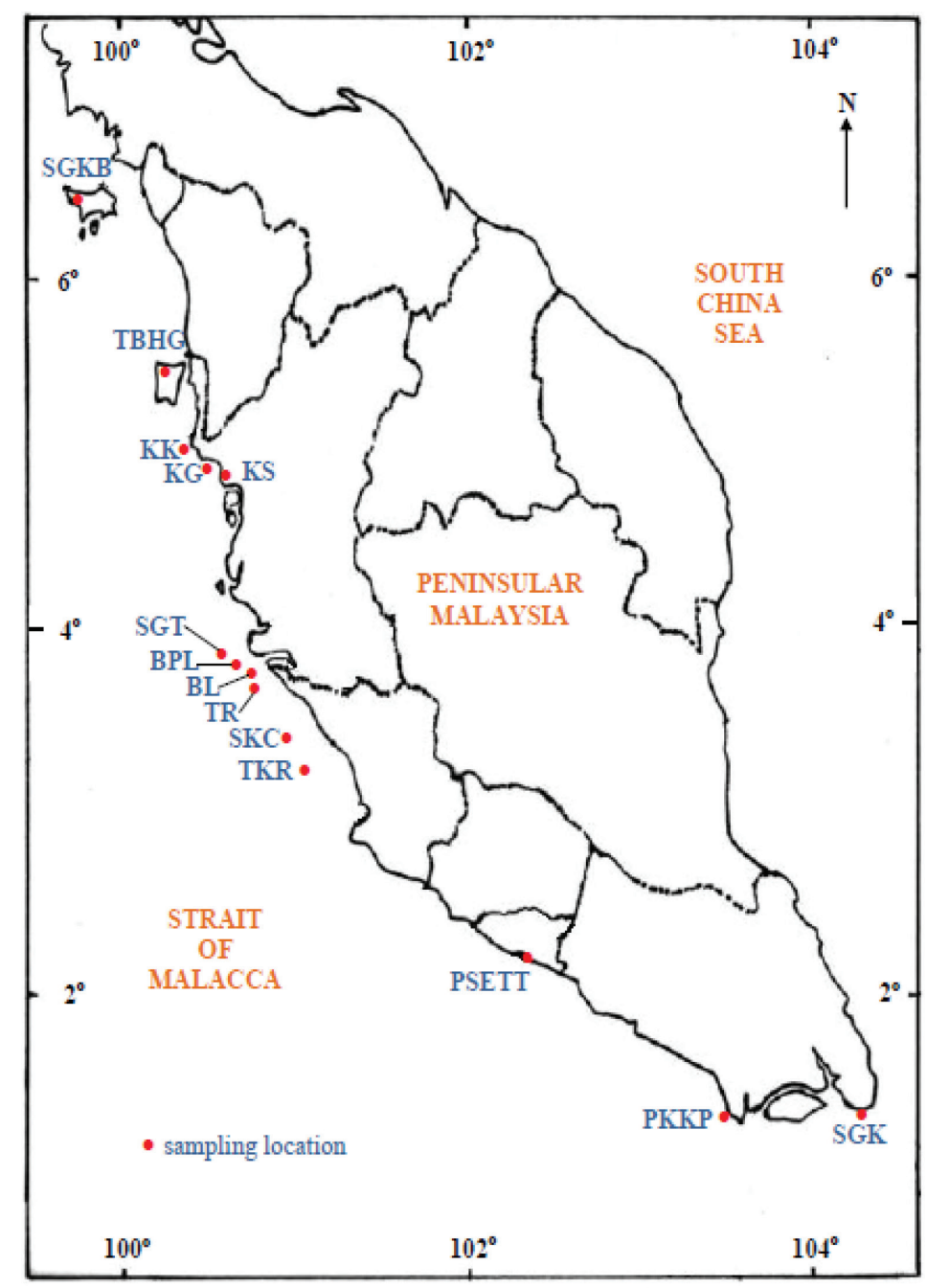

FIGURE 1. Map of Peninsular Malaysia showing the 14 sampling locations for this study The sampling locations are - SGKB: Sungai Kubang Badak; TBHG: Teluk Bahang; KK: Kuala Kurau; KG: Kuala Gula; KS: Kuala Sepetang;

SGT: Sungai Tiang; BPL: Bagan Pasir Laut; BL: Bagan Lipas; TR: Teluk Rhu; SKC: Sekinchan; TKR: Tanjong Karang; PSETT: Portuguese Settlement; PKKP: Pulau Kukup; SGK: Sungai Kapal; indicated as (•) 
geographical position of each sampling location (Table 1). Perak was the only state in which both in- and offshore samples were collected. The samples were preserved immediately in $70 \%$ ethanol (Merck, Germany) upon collection, followed by long-term storage in $95 \%$ ethanol as described by Lai et al. (2010), Wong (2013) and Wong et al. (2015). Fixation and preservation in ethanol was carried out to prevent degradation of DNA by enzymes upon death of the specimens as the latter would subsequently be used for DNA analyses (Black \& Dodson 2003; Bucklin 2009; DíazViloria et al. 2005; DiStefano et al. 1994; Wong 2013). The species and sexes of Acetes spp. were identified under a dissecting microscope (Leica ZOOM 2000 ${ }^{\mathrm{TM}}$, Model No. Z45V, Germany), according to the key characters described by Omori (1975) and Wong (2013) (Table 2).

\section{DNA EXTRACTION, AMPLIFICATION AND SEQUENCING}

DNA was extracted from $25 \mathrm{~g}$ of muscle sample, using i-genomic CTB DNA Extraction Mini Kit (iNtRON Biotechnology Inc., South Korea). Amplification of the $552 \mathrm{bp}$ fragment from the 5'-end of mitochondrial DNA cytochrome $c$ oxidase subunit I (COI) gene was performed using PCR (Saiki et al. 1988) with the primer pair LCO1490 (5'-GGT CAA CAA ATC ATA AAG ATA TTG G-3') and HCO2198 (5' 'TAAACT TCA GGG TGA CCAAAAAAT CA-3') (Folmer et al. 1994). Each PCR reaction mixture contained $2.5 \mu \mathrm{L}$ of $10 \times$ PCR buffer (Vivantis), $1.5 \mathrm{mM}$ of $\mathrm{MgCl}_{2}$ (Vivantis), $50 \mu \mathrm{M}$ of each dNTP (Vivantis), 1 unit (U) of Taq polymerase (Vivantis), $0.3 \mu \mathrm{M}$ of each primer (1 st BASE Pte. Ltd., Singapore), $2 \mu \mathrm{L}$ of DNA template (50 $\mathrm{ng}$ ) and adjusted to a final volume of $25 \mu \mathrm{L}$ with deionised water. The PCR of COI gene was performed on an Eppendorf Mastercycler ${ }^{\circledR}$ Gradient (Eppendorf, Germany) with the following profile: Initial denaturation at $94^{\circ} \mathrm{C}$ for $60 \mathrm{~s}$; five cycles at $94^{\circ} \mathrm{C}$ for $30 \mathrm{~s}, 45^{\circ} \mathrm{C}$ for $90 \mathrm{~s}$ and $72^{\circ} \mathrm{C}$ for $60 \mathrm{~s} ; 35$ cycles at $94^{\circ} \mathrm{C}$ for $30 \mathrm{~s}, 51^{\circ} \mathrm{C}$ for $90 \mathrm{~s}$ and $72^{\circ} \mathrm{C}$ for $60 \mathrm{~s}$; followed by a final extension at $72^{\circ} \mathrm{C}$ for $5 \mathrm{~min}$ (Costa et al. 2007; Hebert et al. 2003). Prior to sequencing, PCR products were purified using the MEGAquick-spin ${ }^{\mathrm{TM}}$ PCR and Agarose Gel DNA Extraction System (iNtRON Biotechnology Inc., South Korea). Purified PCR products were sequenced from both directions, on an ABI Genetic Analyzer 3730 (Applied Biosystems).

\section{SEQUENCE ANALYSIS}

DNA sequence chromatograms were viewed and manually edited with Chromas LITE 2.01 (Technelysium Pty. Ltd., Australia). Homology search was performed with Basic Local Alignment Search Tool (BLAST; Altschul et al. 1990). Alignments of the COI sequences were performed in Molecular Evolutionary Genetics Analysis 4 (MEGA4; Tamura et al. 2007). The aligned nucleotide sequences were then translated into amino acid based on invertebrate mitochondrial genetic code. The sequence variation and base composition of the amplified sequences were analyzed using MEGA4 and DnaSP v5.10 (Librado \& Rozas 2009). When homologous sequences from two individuals differed by one or more than one nucleotide, the sequences were considered as different haplotypes.

\section{PHYLOGENETIC ANALYSES}

Based on all aligned COI sequences, the phylogenetic relationships among haplotypes were examined by four phylogenetic methods to verify whether alternative topologies were supported by different tree-building methods. Prior to these analyses, the best-fit evolutionary model of nucleotide substitution was chosen using corrected Akaike Information Criterion (AIC; Hurvich \& Tsai 1989; Sugiura 1978) in jModelTest 0.1.1 (Posada 2009, 2008).

The calculation of pairwise genetic distances within and among the four Acetes species and the Neighbour-

TABLE 1. Sampling locations of Acetes species along the west coast of Peninsular Malaysia

\begin{tabular}{|c|c|c|c|c|}
\hline State & Sampling Location (Abbreviation) & Latitude & Longitude & Sampling Method \\
\hline Kedah & Sungai Kubang Badak (SGKB) & $6^{\circ} 23^{\prime} 58.75^{\prime \prime} \mathrm{N}$ & $99^{\circ} 43^{\prime} 32.21^{\prime \prime} \mathrm{E}$ & In-shore \\
\hline Pulau Pinang & Teluk Bahang (TBHG) & $5^{\circ} 27^{\prime} 36.91 ’ \mathrm{~N}$ & $100^{\circ} 12^{\prime} 44.51^{\prime \prime} \mathrm{E}$ & In-shore \\
\hline Perak & Kuala Kurau (KK) & $5^{\circ} 0{ }^{\prime} 11.41 ” \mathrm{~N}$ & $100^{\circ} 25^{\prime} 22.47^{\prime \prime} \mathrm{E}$ & In-shore \\
\hline Perak & Kuala Gula (KG) & $4^{\circ} 55^{\prime} 0.35^{\prime \prime} \mathrm{N}$ & $100^{\circ} 27^{\prime} 39.54$ ”'E & In-shore \\
\hline Perak & Kuala Sepetang (KS) & $4^{\circ} 51^{\prime} 12.23 ” \mathrm{~N}$ & $100^{\circ} 32^{\prime} 9.53 ” \mathrm{E}$ & In-shore \\
\hline Perak & Sungai Tiang (SGT) & $3^{\circ} 55^{\prime} 9.28^{\prime \prime} \mathrm{N}$ & $100^{\circ} 36^{\prime} 15.02^{\prime \prime} \mathrm{E}$ & Off-shore \\
\hline Perak & Bagan Pasir Laut (BPL) & $3^{\circ} 49^{\prime} 11.80^{\prime \prime} \mathrm{N}$ & $100^{\circ} 41^{\prime} 4.16^{\prime \prime} \mathrm{E}$ & Off-shore \\
\hline Perak & Bagan Lipas (BL) & $3^{\circ} 45^{\prime} 48.83^{\prime \prime} \mathrm{N}$ & $100^{\circ} 44^{\prime} 18.62$ '” & Off-shore \\
\hline Selangor & Teluk Rhu (TR) & $3^{\circ} 42^{\prime} 47.86^{\prime \prime} \mathrm{N}$ & $100^{\circ} 45^{\prime} 11.12^{\prime \prime} \mathrm{E}$ & Off-shore \\
\hline Selangor & Sekinchan (SKC) & $3^{\circ} 26^{\prime} 42.08^{\prime \prime} \mathrm{N}$ & $100^{\circ} 54^{\prime} 39.76^{\prime \prime} \mathrm{E}$ & Off-shore \\
\hline Selangor & Tanjong Karang (TKR) & $3^{\circ} 19^{\prime} 48.37^{\prime \prime} \mathrm{N}$ & $101^{\circ} 2^{\prime} 20.32^{\prime \prime} \mathrm{E}$ & Off-shore \\
\hline Malacca & Portuguese Settlement (PSETT) & $2^{\circ} 10^{\prime} 57.14 ” \mathrm{~N}$ & $102^{\circ} 15^{\prime} 57.91$ '” & In-shore \\
\hline Johor & Pulau Kukup (PKKP) & $1^{\circ} 19^{\prime} 5.39^{\prime \prime} \mathrm{N}$ & $103^{\circ} 26^{\prime} 37.77^{\prime \prime} \mathrm{E}$ & In-shore \\
\hline Johor & Sungai Kapal (SGK) & $1^{\circ} 20^{\prime} 51.04 ’ \mathrm{~N}$ & $104^{\circ} 13^{\prime} 12.94^{\prime \prime} \mathrm{E}$ & In-shore \\
\hline
\end{tabular}

(Wong 2013; Wong et al. 2015) 


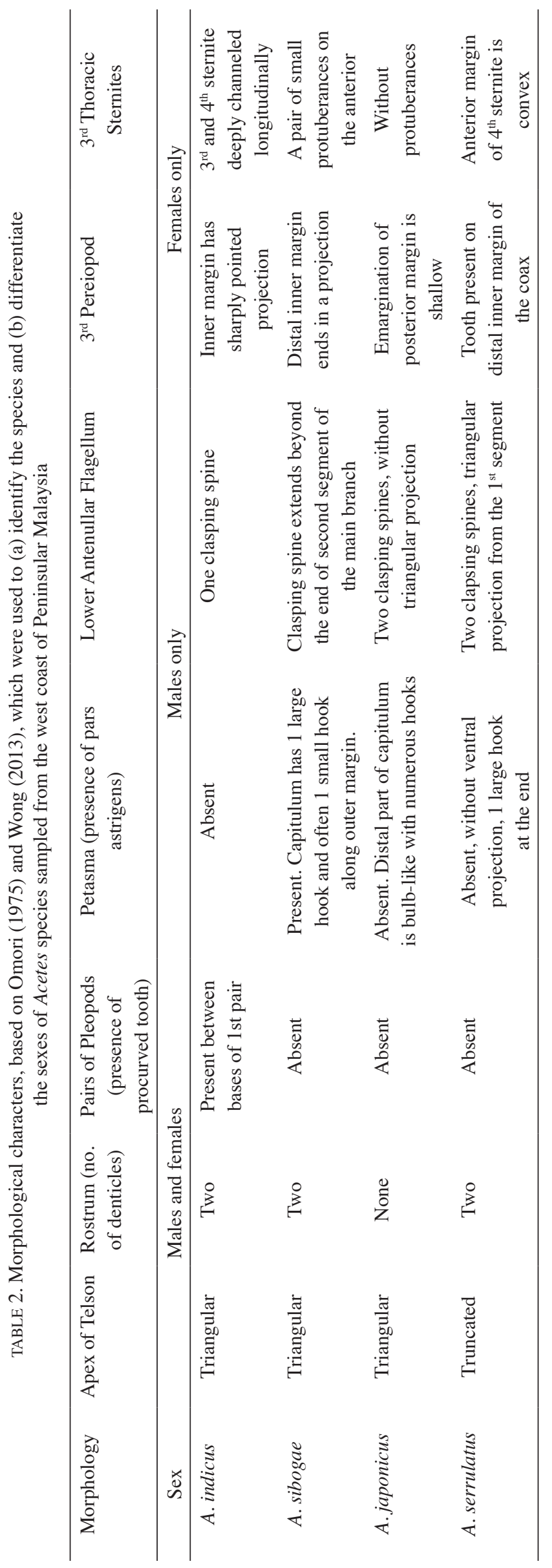


Joining (NJ; Saitou \& Nei 1987) tree were based on the substitution model of Kimura's Two Parameter (K2P; Kimura 1980) and were constructed using MEGA4 in which the stabilities of the derived clusters in phylogenetic trees were accessed by 2000 replications of non-parametric bootstrapping (Felsenstein 1985).

The Maximum Parsimony (MP; Camin \& Sokal 1965) tree was constructed from a heuristic search using TreeBisection-Reconnection (TBR) in Phylogeny Analysis Using Parsimony (PAUP* 4.0b10; Swofford 2002). Nodal support was accessed through non-parametric bootstrapping using the heuristic search option of 1000 replications with 10 random addition-sequence replicates. The Maximum Likelihood (ML; Felsenstein 1981) tree was constructed using the starting tree obtained by BioNJ (Gascuel 1997) and Nearest Neighbour Interchange (NNI; Jarvis et al. 1983) branch swapping arrangements in PhyML 3.0 (Guindon et al. 2005). The data set was bootstrapped for 1000 replications.

Bayesian Inference (BI) was performed using MrBayes 3.1.2 (Huelsenbeck \& Ronquist 2001; Ronquist \& Huelsenbeck 2003) with substitution model parameters set to lset nst=6 rates=gamma and all priors were left default to allow estimation of the parameters from the data. Each BI was conducted three times to check for consistency of results. Two runs of four Metropolis-coupled Markov Chain Monte Carlo (MCMC) chains each (one cold chain and three heated chains, default temperature $=0.20$ ) were run for four million generations $(\mathrm{mcmc}$ ngen $=4000000)$ and sampled every 1000th generations (sample freq $=$ 1000). When the average standard deviation of split frequencies was less than $0.01,25 \%$ of the samples were discarded as burn-in (sump burnin $=1000$ ). The remaining trees were used to calculate the posterior probabilities (PP) and to produce the $50 \%$ majority-rule consensus tree after discarding burn-in samples in each analysis. Probabilities of $95 \%$ or higher were considered significant support. All the phylogenetic trees were rooted with Sergestes similis (GenBank Accession Number: DQ882152) as outgroup and displayed with TreeView 1.6.6 (Page 1996).

In addition, a haplotype network was constructed for $A$. indicus and A. sibogae using the TCS 1.13 software (Clement et al. 2000), which employs a 95\% statistical parsimony method (Templeton et al. 1992). For the intraspecific variation, haplotype diversity ( $h$; Nei 1987) and nucleotide diversity ( $\pi$; Nei 1987) was computed using DnaSP v5 based on segregating sites $(S)$.

Population structure for each species was carried out using Analysis of Molecular VAriance (AMOVA; Excoffier et al. 1992) to produce the pairwise $\Phi$-statistics (Weir \& Cockerham 1984) in Arlequin (Excoffier \& Lischer 2010). The significant levels of the AMOVA and pairwise $\Phi$-statistics were tested with 10000 permutations. When the overall AMOVA was statistically significant, a Mantel test (Mantel 1967) was performed in XLSTAT v.2010.3.06 to determine if genetic distance was due to geographical distance. Statistical significance was determined by 10000 permutations.
Demographic histories were investigated using the Neutrality Tests and Mismatch Distribution Analysis. Tajima's $D$ (Tajima 1989), Fu's $F_{S}(\mathrm{Fu} 1997)$ and the $R_{2}$ (Ramos-Onsins \& Rozas 2002) and their significance was tested with 10000 coalescent simulations (Hudson 1990) in DnaSP v5. Mismatch distribution was performed with Arlequin v3.5 and mismatch figures were created using DnaSP v5. The parameters of the mismatch distribution or demographic expansion before and after population growth $\left(\Theta_{0}\right.$ and $\left.\Theta_{1}\right)$ and time since expansion, $\tau$, expressed in units of mutational time (Rogers 1995; Rogers \& Harpending 1992) were estimated using generalised non-linear leastsquares approach (Schneider \& Excoffier 1999). Their respective $95 \%$ confidence intervals (CI) were obtained by parametric bootstrapping with 10000 permutations. The fit between the observed and expected distributions under population growth was evaluated by the sum of square deviations (SSD; Schneider \& Excoffier 1999) and Harpending's Raggedness Index ( $r$; Harpending 1994) with 10000 bootstrap replicates.

\section{RESULTS}

\section{SPECIES IDENTIFICATION OF ACETES}

From a total of 159 specimens collected, four main Acetes species, namely, Acetes indicus $(n=69)$, A. serrulatus ( $n=65)$, A. japonicus $(n=13)$ and A. sibogae $(n=12)$ were identified based on the key morphological characters described by Omori (1975) and Wong (2013). Males and females were identified by the presence of a pair of protuberances (genital coxae) between the third pereiopods and first pleopods, a petasma and lower antenullar flagellum with spine(s) in males but absent in females. The different species of Acetes were differentiated based on the apex of telson, petasma and antennular flagellum of males and third thoracic sternite of females (Table 2).

\section{CYTOCHROME $C$ OXIDASE SUBUNIT I (COI) GENE}

The 552 bp of the COI gene fragment (GenBank Accession Number: HQ630429-HQ630587) amplified in this study were obtained for 159 specimens and showed 46 haplotypes (Table 3): 11 haplotypes were identified for $A$. indicus, 31 haplotypes for $A$. serrulatus, two haplotypes for A. japonicus and two haplotypes for $A$. sibogae. From the multiple sequence alignment of 46 haplotypes, 167 variable sites were found, of which 144 and 23 were parsimony informative sites and singleton sites, respectively. No insertions or deletions (indels) were found. Most of the variations (139 sites, $83 \%$ ) occurred at the third codon position, while 26 variable sites $(16 \%)$ were at the first position. Only two variable sites $(1 \%)$ were at the second position.

The mean nucleotide composition of each Acetes species is shown in Table 4, together with the base composition according to first, second and third codon position. The pattern of nucleotide substitution was biased in favour of 
TABLE 3. List of specimens used in this study and their GenBank accession numbers

\begin{tabular}{|c|c|c|c|}
\hline Species & $\begin{array}{c}\text { Lab Identification } \\
\text { (specimen no._sex of specimen }{ }^{1}{ }_{-} \text {sampling } \\
\text { location }^{2} \text { ) }\end{array}$ & Haplotype & GenBank Accession Number \\
\hline \multirow[t]{56}{*}{ Acetes indicus } & AI9_f_BPL2 & ai1 & HQ630429 \\
\hline & AI14_m_SGT1 & ai1 & HQ630430 \\
\hline & AI15_f_SGT1 & ai1 & HQ630431 \\
\hline & AI26_f_PSETT4 & ai1 & HQ630432 \\
\hline & AI27_m_PSETT4 & ai2 & HQ630433 \\
\hline & AI28_m_BPL2 & ai1 & HQ630434 \\
\hline & AI29_m_PSETT4 & ai3 & HQ630435 \\
\hline & AI30_f_PSETT4 & ai4 & HQ630436 \\
\hline & AI31_m_PSETT4 & ai4 & HQ630437 \\
\hline & AI32_f_PSETT4 & ai5 & HQ630438 \\
\hline & AI33_m_PSETT4 & ai4 & HQ630439 \\
\hline & AI34_f_PSETT4 & ai6 & HQ630440 \\
\hline & AI35_m_SGT5 & ai1 & HQ630441 \\
\hline & AI36_f_SGT5 & ai7 & HQ630442 \\
\hline & AI37_m_SGT6 & ai1 & HQ630443 \\
\hline & AI38_f_SGT6 & ai1 & HQ630444 \\
\hline & AI39_m_BPL7 & ai1 & HQ630445 \\
\hline & AI40_f_BPL7 & ai1 & HQ630446 \\
\hline & AI41_m_BPL8 & ai1 & HQ630447 \\
\hline & AI43_m_BL9 & ai1 & HQ630448 \\
\hline & AI44_f_BL9 & ai1 & HQ630449 \\
\hline & AI45_m_BL10 & ai4 & HQ630450 \\
\hline & AI46_f_BL10 & ai1 & HQ630451 \\
\hline & AI47_m_SKC11 & ai1 & HQ630452 \\
\hline & AI49_m_TKR12 & ai1 & HQ630453 \\
\hline & AI50_f_TKR12 & ai8 & HQ630454 \\
\hline & AI52_f_TR13 & ai1 & HQ630455 \\
\hline & AI53_m_TKR14 & ai1 & HQ630456 \\
\hline & AI55_m_SKC15 & ai1 & HQ630457 \\
\hline & AI56_f_SKC15 & ai1 & HQ630458 \\
\hline & AI57_m_BPL16 & ai1 & HQ630459 \\
\hline & AI58_f_BPL16 & ai1 & HQ630460 \\
\hline & AI59_m_SGT17 & ai1 & HQ630461 \\
\hline & AI60_f_SGT17 & ai1 & HQ630462 \\
\hline & AI62_f_BL9 & ai1 & HQ630463 \\
\hline & AI63_m_BL10 & ai1 & HQ630464 \\
\hline & AI64_f_BL10 & ai1 & HQ630465 \\
\hline & AI65_m_SKC11 & ai1 & HQ630466 \\
\hline & AI66_f_-SKC11 & ai1 & HQ630467 \\
\hline & AI67_m_SKC15 & ai1 & HQ630468 \\
\hline & AI68_f_SKC15 & ai8 & HQ630469 \\
\hline & AI69_m_TKR12 & ai1 & HQ630470 \\
\hline & AI70_f_TKR12 & ai1 & HQ630471 \\
\hline & AI72_f_TKR14 & ai1 & HQ630472 \\
\hline & AI73_m_TR13 & ai1 & HQ630473 \\
\hline & AI74_f_TR13 & ai1 & HQ630474 \\
\hline & AI75_m_TR13 & ai9 & HQ630475 \\
\hline & AI76_f_TR13 & ai10 & HQ630476 \\
\hline & AI77_m_KK19 & ai4 & HQ630477 \\
\hline & AI78_f_KK19 & ai4 & HQ630478 \\
\hline & AI79_m_KK19 & ai4 & HQ630479 \\
\hline & AI81_m_KK19 & ai4 & HQ630480 \\
\hline & AI82_f_KK19 & ai4 & HQ630481 \\
\hline & AI83_m_KG26 & ai4 & HQ630482 \\
\hline & AI84_f_KG26 & ai4 & HQ630483 \\
\hline & AI85_m_KG26 & ai4 & HQ630484 \\
\hline
\end{tabular}




\begin{tabular}{|c|c|c|c|}
\hline \multirow[t]{14}{*}{ Species } & $\begin{array}{c}\text { Lab Identification } \\
\begin{array}{c}\text { (specimen no._sex of specimen }{ }^{1} \_ \text {sampling } \\
\text { location }{ }^{2} \text { ) }\end{array}\end{array}$ & Haplotype & GenBank Accession Number \\
\hline & AI86_f_KG26 & ai4 & HQ630485 \\
\hline & AI87_m_KG26 & ai4 & HQ630486 \\
\hline & AI88_f_KG26 & ai4 & HQ630487 \\
\hline & AI89_m_PKKP29 & ai1 & HQ630488 \\
\hline & AI90_f_PKKP29 & ai1 & HQ630489 \\
\hline & AI92f_PKKP29 & ai1 & HQ630490 \\
\hline & AI93_m_PKKP29 & ai1 & HQ630491 \\
\hline & AI94_f_PKKP29 & ai11 & HQ630492 \\
\hline & AI95_m_SGK30 & ai1 & HQ630493 \\
\hline & AI96_f_SGK30 & ai1 & HQ630494 \\
\hline & AI97_m_SGK30 & ai1 & HQ630495 \\
\hline & AI99_m_SGK30 & ai1 & HQ630496 \\
\hline & AI100_f_SGK30 & ai1 & HQ630497 \\
\hline \multirow[t]{43}{*}{ Acetes serrulatus } & AS3_m_BPL2 & as 1 & HQ630498 \\
\hline & AS4_m_SGT1 & as2 & HQ630499 \\
\hline & AS5_f_BPL2 & as2 & HQ630500 \\
\hline & AS6_f_BPL2 & as 1 & HQ630501 \\
\hline & AS7_m_BPL2 & as 3 & HQ630502 \\
\hline & AS8_m_SGT1 & as2 & HQ630503 \\
\hline & AS9_m_SGT5 & as 4 & HQ630504 \\
\hline & AS10_f_SGT5 & as 5 & HQ630505 \\
\hline & AS11_m_SGT6 & as 1 & HQ630506 \\
\hline & AS12_f_SGT6 & as6 & HQ630507 \\
\hline & AS13_m_BPL7 & as 7 & HQ630508 \\
\hline & AS 14_f_BPL7 & as2 & HQ630509 \\
\hline & AS15_m_BPL8 & as2 & HQ630510 \\
\hline & AS16_f_BPL8 & as8 & HQ630511 \\
\hline & AS17_m_BL9 & as 1 & HQ630512 \\
\hline & AS18_f_BL9 & as9 & HQ630513 \\
\hline & AS19_m_BL10 & as2 & HQ630514 \\
\hline & AS20_f_BL10 & as2 & HQ630515 \\
\hline & AS21_m_SKC11 & as 1 & HQ630516 \\
\hline & AS22_f_SKC11 & as8 & HQ630517 \\
\hline & AS23_m_TKR12 & as 10 & HQ630518 \\
\hline & AS24_f_TKR12 & as 1 & HQ630519 \\
\hline & AS25_m_TR13 & as 1 & HQ630520 \\
\hline & AS26_f_TR13 & as11 & HQ630521 \\
\hline & AS27_m_SGT1 & as12 & HQ630522 \\
\hline & AS28_f_-SGT1 & as 13 & HQ630523 \\
\hline & AS30_f_BPL2 & as 1 & HQ630524 \\
\hline & AS31_m_SGT5 & as 1 & HQ630525 \\
\hline & AS32_f_SGT5 & as14 & HQ630526 \\
\hline & AS33_m_SGT6 & as 2 & HQ630527 \\
\hline & AS34_f_SGT6 & as 15 & HQ630528 \\
\hline & AS35_m_BPL7 & as 2 & HQ630529 \\
\hline & AS36_f_BPL7 & as 16 & HQ630530 \\
\hline & AS37_m_BPL8 & as 17 & HQ630531 \\
\hline & AS38_f_BPL8 & as 18 & HQ630532 \\
\hline & AS39_m_BL9 & as 19 & HQ630533 \\
\hline & AS40_f_BL9 & as 1 & HQ630534 \\
\hline & AS41_m_BL10 & as 20 & HQ630535 \\
\hline & AS42_f_BL10 & as 1 & HQ630536 \\
\hline & AS43_m_SKC11 & as 21 & HQ630537 \\
\hline & AS44_f_SKC11 & as 1 & HQ630538 \\
\hline & AS45_m_TKR12 & as 22 & HQ630539 \\
\hline & AS46_f_TKR12 & as 23 & HQ630540 \\
\hline
\end{tabular}


Continued (TABLE 3)

\begin{tabular}{|c|c|c|c|}
\hline Species & $\begin{array}{c}\text { Lab Identification } \\
\text { (specimen no._sex of specimen }{ }^{1} \text { sampling }_{\text {secation }} \text { ) } \\
\text { local }^{2}\end{array}$ & Haplotype & GenBank Accession Number \\
\hline & AS47_m_TR13 & as1 & HQ630541 \\
\hline & AS48_f_TR13 & as 24 & HQ630542 \\
\hline & AS49_m_TKR14 & as8 & HQ630543 \\
\hline & AS50_f_TKR14 & as 25 & HQ630544 \\
\hline & AS51_m_SKC15 & as1 & HQ630545 \\
\hline & AS52_f_SKC15 & as1 & HQ630546 \\
\hline & AS53_m_BPL16 & as 26 & HQ630547 \\
\hline & AS54_f_BPL16 & as 27 & HQ630548 \\
\hline & AS55_m_SGT17 & as8 & HQ630549 \\
\hline & AS56_f_SGT17 & as 7 & HQ630550 \\
\hline & AS58_f_TR13 & as8 & HQ630551 \\
\hline & AS64_f_SKC15 & as 2 & HQ630552 \\
\hline & AS69_m_PKKP29 & as1 & HQ630553 \\
\hline & AS70_f_PKKP29 & as1 & HQ630554 \\
\hline & AS71_m_PKKP29 & as 1 & HQ630555 \\
\hline & AS72_f_PKKP29 & as28 & HQ630556 \\
\hline & AS73_m_PKKP29 & as2 & HQ630557 \\
\hline & AS75_m_SGK30 & as 1 & HQ630558 \\
\hline & AS76_f_SGK30 & as29 & HQ630559 \\
\hline & AS77_m_SGK30 & as30 & HQ630560 \\
\hline & AS79_m_SGK30 & as31 & HQ630561 \\
\hline & AS80_f_SGK30 & as 18 & HQ630562 \\
\hline \multirow[t]{13}{*}{ Acetes japonicus } & AJ1_m_TBHG & aj1 & HQ630563 \\
\hline & AJ2_f_TBHG & aj2 & HQ630564 \\
\hline & AJ3_m_TBHG & aj2 & HQ630565 \\
\hline & AJ4_f_TBHG & aj2 & HQ630566 \\
\hline & AJ5_m_TBHG & aj1 & HQ630567 \\
\hline & AJ6_f_TBHG18 & aj2 & HQ630568 \\
\hline & AJ7_m_KG26 & aj1 & HQ630569 \\
\hline & AJ8_f_KG26 & aj2 & HQ630570 \\
\hline & AJ10_f_KG26 & aj2 & HQ630571 \\
\hline & AJ11_m_KG26 & aj1 & HQ630572 \\
\hline & AJ12_f_KG26 & aj1 & HQ630573 \\
\hline & AJ13_f_KK19 & aj2 & HQ630574 \\
\hline & AJ18_f_KK19 & aj1 & HQ630575 \\
\hline \multirow[t]{12}{*}{ Acetes sibogae } & Asi1_m_SGKB28 & asi1 & HQ630576 \\
\hline & Asi2_f_SGKB28 & asi1 & HQ630577 \\
\hline & Asi3_m_SGKB28 & asi1 & HQ630578 \\
\hline & Asi4_f_SGKB28 & asi2 & HQ630579 \\
\hline & Asi5_m_SGKB28 & asi1 & HQ630580 \\
\hline & Asi6_f_SGKB28 & asi1 & HQ630581 \\
\hline & Asi7_m_KS27 & asi1 & HQ630582 \\
\hline & Asi8_f_KS27 & asi1 & HQ630583 \\
\hline & Asi9_m_KS27 & asi1 & HQ630584 \\
\hline & Asi10_f_KS27 & asi1 & HQ630585 \\
\hline & Asi11_m_KS27 & asi1 & HQ630586 \\
\hline & Asi12_f_KS27 & asi1 & HQ630587 \\
\hline
\end{tabular}

${ }^{1}$ f: female, m: male; ${ }^{2}$ sampling location: refer to Table 1

122 transitions ( $\mathrm{Ts}, 44 \mathrm{~A} \leftrightarrow \mathrm{G}$ and $78 \mathrm{~T} \leftrightarrow \mathrm{C}$ changes) over 95 transversions (Tv, $62 \mathrm{~T} \leftrightarrow \mathrm{A}, 8 \mathrm{~T} \leftrightarrow \mathrm{G}, 20 \mathrm{C} \leftrightarrow \mathrm{A}$ and 5 $\mathrm{C} \leftrightarrow \mathrm{G}$ changes), yielding a Ts/Tv ratio of 1.28. Furthermore, from the 196 mutations, 194 (99\%) were synonymous mutations and two (1\%) were non-synonymous mutations. Non-synonymous mutations that resulted in amino acid substitutions occurred at sites 253, 301 and 434, resulting in a change from leucine to methionine, alanine to serine, serine to threonine, respectively. The substitutions resulted in a change of chemically similar amino acids. Overall, the pattern of base composition nucleotide substitution was similar among Acetes species. 
TABLE 4. Base composition (\%) of COI gene amplified for each Acetes species

\begin{tabular}{|c|c|c|c|c|c|c|c|c|c|c|c|c|c|c|c|c|c|}
\hline & \multicolumn{4}{|c|}{ First codon } & \multicolumn{4}{|c|}{ Second codon } & \multicolumn{4}{|c|}{ Third codon } & \multicolumn{5}{|c|}{ Overall } \\
\hline & $\mathrm{T}$ & $\mathrm{C}$ & A & G & $\mathrm{T}$ & $\mathrm{C}$ & A & G & $\mathrm{T}$ & $\mathrm{C}$ & A & G & $\mathrm{T}$ & $\mathrm{C}$ & A & G & $\mathrm{A}+\mathrm{T}$ \\
\hline A. indicus & 23.8 & 16.8 & 28.4 & 31.0 & 45.7 & 23.8 & 12.5 & 18.1 & 36.9 & 9.1 & 51.5 & 2.5 & 35.5 & 16.6 & 30.8 & 17.2 & 66.3 \\
\hline A.serrulatus & 23.9 & 16.9 & 28.8 & 30.4 & 45.7 & 23.9 & 12.5 & 17.9 & 38.7 & 8.7 & 50.2 & 2.4 & 36.1 & 16.5 & 30.5 & 16.9 & 66.6 \\
\hline A. japonicus & 20.7 & 19.6 & 28.8 & 31.1 & 45.7 & 23.9 & 12.5 & 17.9 & 33.2 & 19.6 & 44.3 & 3.0 & 33.2 & 21.0 & 28.5 & 17.3 & 61.7 \\
\hline A. sibogae & 19.6 & 20.1 & 29.3 & 31.0 & 45.7 & 23.9 & 12.5 & 17.9 & 35.4 & 14.7 & 41.8 & 8.2 & 33.5 & 19.6 & 27.9 & 19.0 & 61.4 \\
\hline Overall & 23.3 & 17.3 & 28.7 & 30.8 & 45.7 & 23.9 & 12.5 & 18.0 & 37.2 & 10.2 & 49.6 & 2.9 & 35.4 & 17.1 & 30.3 & 17.2 & 65.7 \\
\hline
\end{tabular}

\section{PHYLOGENETIC ANALYSES}

Phylogenetic trees constructed based on Neighbour-Joining (NJ) and Maximum Likelihood (ML), Maximum Parsimony (MP) and Bayesian Inference (BI) are shown in Figures 2 and 3 , respectively. NJ, ML, MP and BI consistently produced trees with the same overall topology, which are four major clades, namely, clade $a i, a s, a j$ and asi for $A$.indicus, A. serrulatus, A. japonicus and $A$, sibogae, respectively. The four major clades corresponded well to the four identified Acetes species based on morphological characters (Omori 1975; Wong

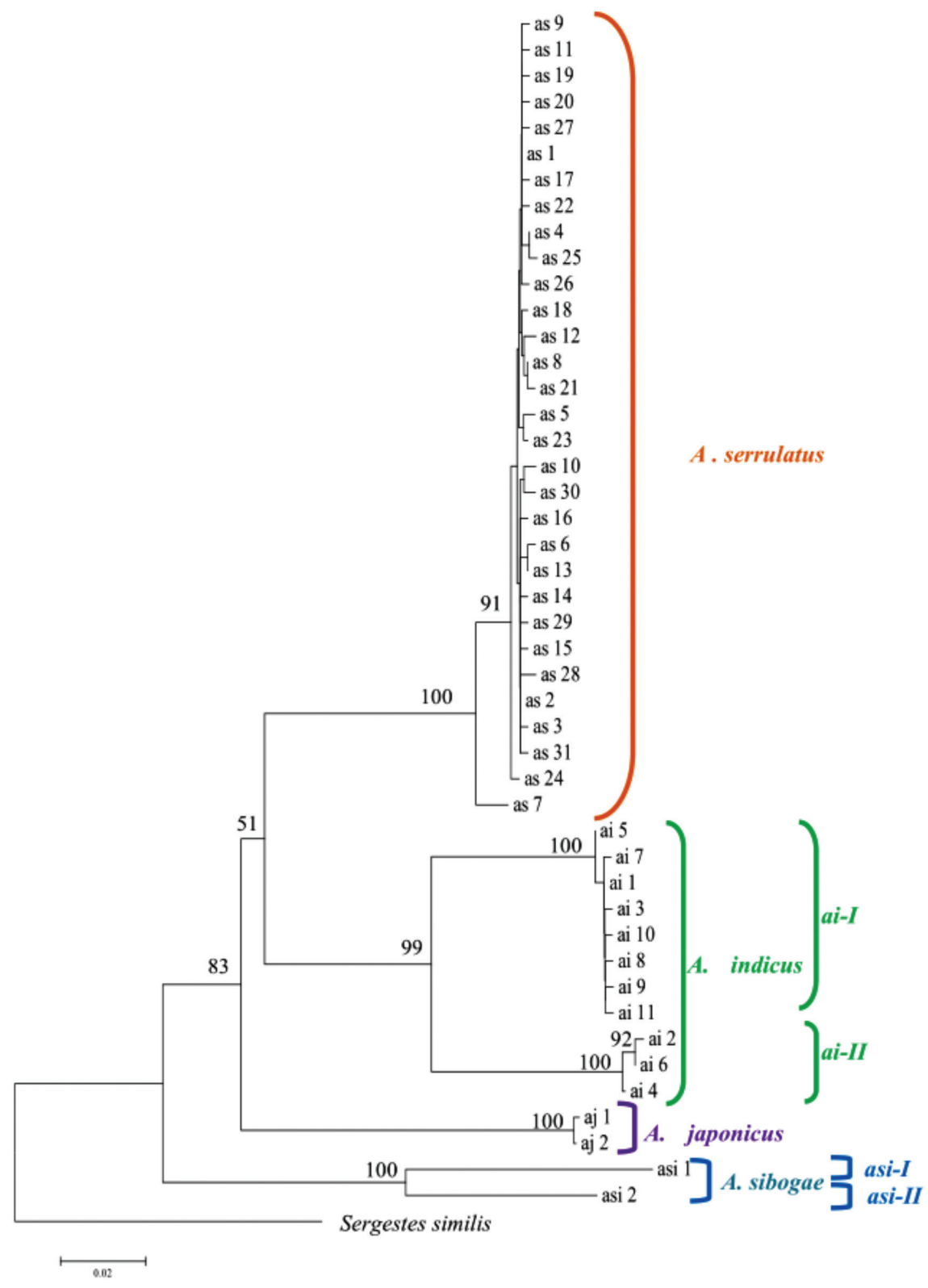

FIGURE 2. Neighbour-Joining (NJ) phylogram showing the relationships among COI mtDNA haplotypes of the Acetes species shrimps 


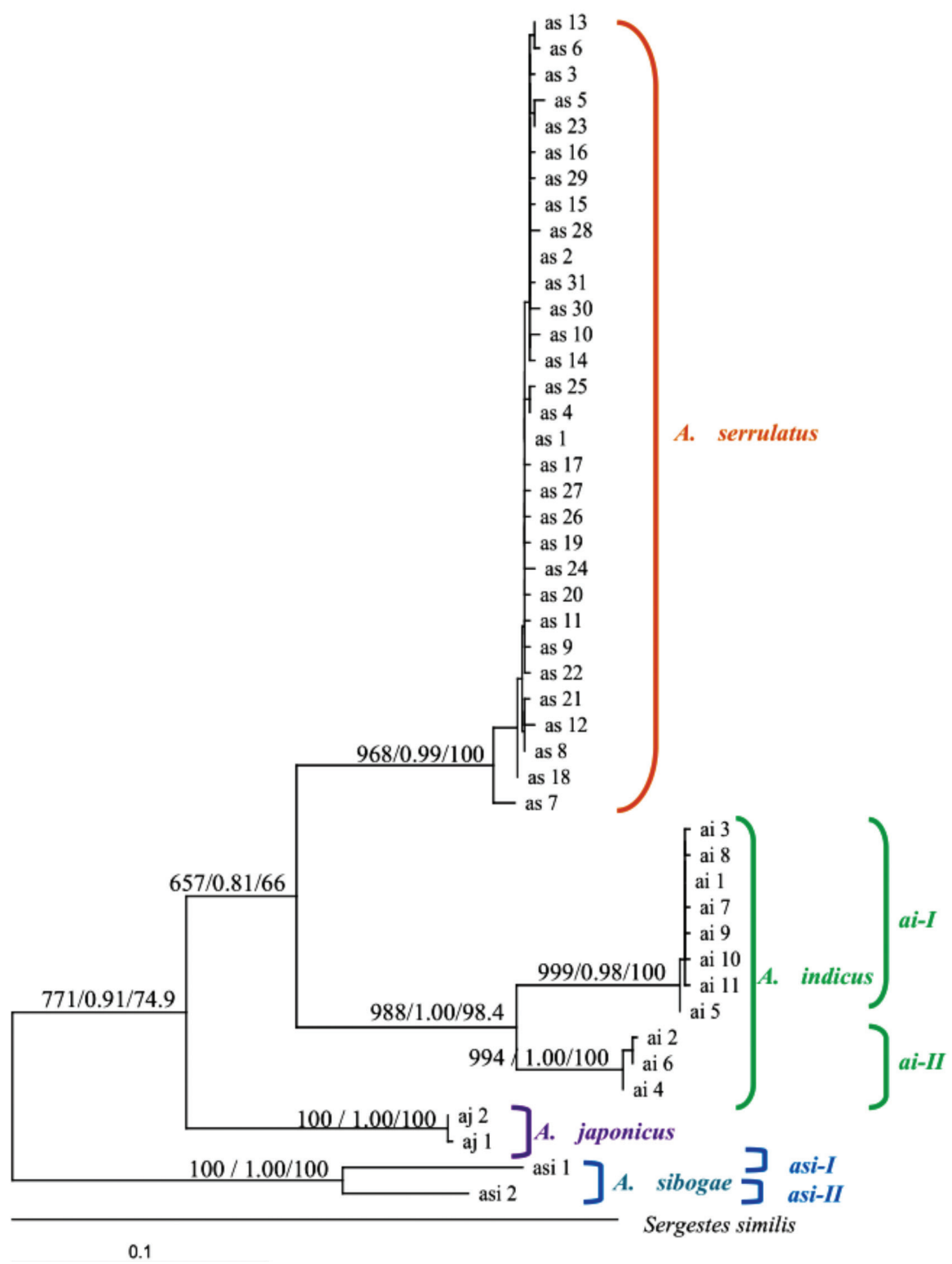

FIGURE 3. Maximum Likelihood (ML) tree from COI mtDNA haplotype data under the best-fitting model HKY $+\mathrm{I}+\mathrm{G}$ selected by jModeltest

The parameters were as follows: model $=$ HKY85, number of substitution types $(\mathrm{nst})=2$, proportion of invariable sites $(p$-invar $)=0.6220$, Transition/Transversion ratio $=4.2197$ and gamma $(\gamma)$ distribution shape parameter $(\alpha=1.7320)$.

The value at each node represents the bootstrap value (BS, \%) for ML/ posterior probability (PP) for BI / (BS\%) for MP

2013). Each clade was strongly supported by high bootstrap (BS) values of $97-100 \%$ and posterior probability (PP) values of 0.99-1.00. Furthermore, A. indicus and A. sibogae were shown to cluster into two distinct clades, respectively.

The mean percentage of nucleotide sequence divergence (K2P) within and between Acetes species are summarized in Table 5. The interspecific variation ranged from $14.50-20.50 \%$. This result indicates that A. sibogae was the most divergent among the four Acetes species, followed by $A$. japonicus, A. serrulatus and A. indicus. In addition, the two distinct clades of $A$. indicus and $A$. sibogae showed a mean sequence divergence value of $8.94 \%$ and $10.93 \%$, respectively.
In the statistical parsimony haplotype network produced using TCS (Figure 4), both the Acetes indicus and A. sibogae formed two separate networks. For A. indicus, the clade ai-II haplotypes could not be parsimoniously connected to the ai-I clade network at the $95 \%$ significance criterion and the corresponding sequences were separated by at least 44 mutational steps from ai-I clade haplotypes. Similarly, the haplotype asi2 was separated by 52 mutation steps from the haplotype asil. For A.japonicus, both aj1 and aj2 haplotypes were connected. All haplotypes of A. serrulatus, with the exception of as 7 and as 25 , were connected to either one of the common haplotypes, as 1 and as 2 , with an overall 
TABLE 5. Mean nucleotide sequence divergence (\%) estimated with Kimura's Two Parameter (K2P), based on haplotypes only: (a) between and within Acetes species and outgroup, Sergestes similis; (b) between and within two distinct clades of A. indicus (c) between and within two distinct clades of A. sibogae

\begin{tabular}{|c|c|c|c|c|c|}
\hline Species & A. indicus & A. serrulatus & A.japonicus & A. sibogae & S. similis (outgroup) \\
\hline Acetes indicus & 4.08 & & & & \\
\hline A. serrulatus & 14.49 & 0.63 & & & \\
\hline A. japonicus & 17.86 & 14.69 & 0.18 & & \\
\hline A. sibogae & 20.47 & 19.58 & 19.89 & 10.30 & \\
\hline S. similis (outgroup) & 21.35 & 19.32 & 21.21 & 21.57 & - \\
\hline
\end{tabular}

(b) Interclade variation of A. indicus

\begin{tabular}{lcc}
\hline Clade & ai-I & ai-II \\
\hline ai-I & 0.32 & \\
ai-II & 8.94 & 0.36 \\
\hline
\end{tabular}

(c) Interclade variation of $A$. sibogae

\begin{tabular}{lcc}
\hline Clade & asi-I & asi-II \\
\hline asi-I & - & \\
asi-II & 10.30 & -
\end{tabular}

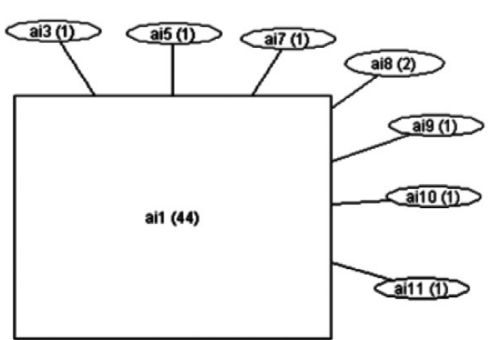

clade $a i-I$

(a) A. indicus

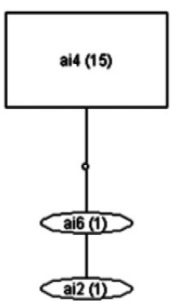

clade $a i-I I$

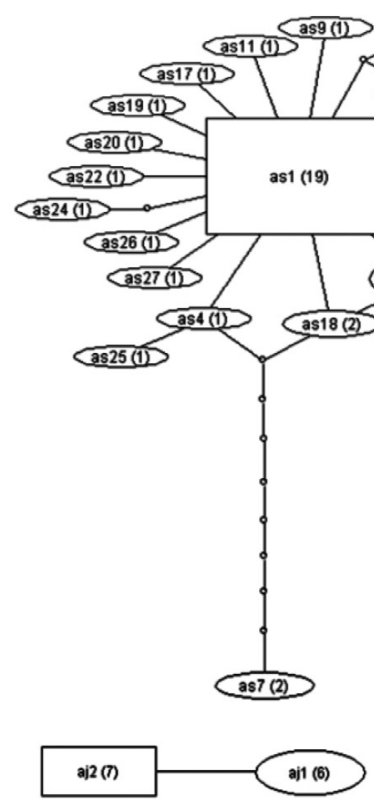

(c) A. japonicus

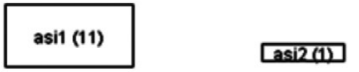

(d) A. sibogae

FIGURE 4. Parsimony network of (a) A. indicus, (b) A. serrulatus, (c) A. japonicus and (d) A. sibogae based on 552 bp of COI amplified in this study

Each oval represents a haplotype and the haplotype in a square has the highest outgroup probability. The size of the oval or square corresponds to the haplotype frequency. The haplotype abbreviations correspond to the haplotypes as reported in Table 2, and the number in parentheses corresponds to the frequency of the haplotype. Small circles indicate the number of mutational changes among haplotypes 
appearance of the network resembling a radiating star-like shape (Figure 4).

There were 11 haplotypes detected for A. indicus (Table 6). The ail haplotype was the most common and occurred in all but two locations, Kuala Gula and Kuala Kurau. The haplotype diversity for A. indicus was moderate $(h=0.552)$ while nucleotide diversity was high $(\pi=0.031)$ in the overall samples. However, when the two clades were analysed separately, low levels of both $h(a i-I=0.286, a i-I I=0.228)$ and $\pi(a i-I=0.001$, ai- $I I=$ 0.001 ) were observed. A. serrulatus had 31 haplotypes in total with as 1 being the most common followed by as 2 , as 8, as 7 and as 18 , respectively (Table 7). The overall haplotype diversity was high $(h=0.886)$ while overall nucleotide diversity was low $(\pi=0.004)$.

Both $A$. japonicus and A. sibogae had only two haplotypes each. Both haplotypes occurred in all four locations where A.japonicus was detected and the overall $h$ was moderate $(0.540)$ while $\pi$ was low $(0.001)$ (Table $8)$. The overall $h$ and $\pi$ was low for $A$. sibogae with one location having both haplotypes (Sungai Kubang Badak) while Kuala Sepetang had only one haplotype (Table 9).

The AMOVA results for each Acetes species are reported in Table 10. Only A. indicus showed significant population differentiation with $75.8 \%$ of the molecular variance due to variation among the sampling sites. There was also significant differentiation between the two clades ai- $I$ and $a i-I I(99.2 \%)$. The pairwise $\Phi_{\mathrm{ST}}$ was not significant for Kuala Kurau, Kuala Gula and the Portuguese Settlement when they were compared with one another. However, they were significant when each was compared with the other populations (Table 11). The Mantel Test indicated no correlation between $\Phi_{\mathrm{ST}}$ estimates and geographical distribution $(r=0.106, p>0.05)$. Similar to AMOVA, the pairwise $\Phi_{\mathrm{ST}}$ values were not significant for the other three Acetes species (detailed results not shown; Wong 2013).

All the Neutrality Tests were significant for $A$. serrulatus while A.japonicus was the only species that did not show any significance in these tests (Table 12). Although none of the Neutrality Tests were significant for the pooled $A$. indicus samples, the ai-I clade, which was analysed separately was significant for all the tests while the $a i-I I$ clade was significant only for $R_{2}$. Similarly, $A$. sibogae was only significant for Tajima's $D$.

A bimodal mismatch distribution was observed for $A$. sibogae $(S S D=0.040,0.01<p<0.05)$ (Figure 5). Similarly, a bimodal mismatch distribution was observed for the pooled samples of $A$. indicus ( SSD $=0.112, p>0.05)$, which did not differ significantly from the distribution expected for population expansion. When the $a i-I$ and $a i-I I$ clades were analysed separately, both showed a unimodal distribution that did not differ significantly from the distribution expected for population expansion (ai-I, $S S D=0.005, p>0.05 ; a i-I I, S S D=0.040, p>0.05)$, with peaks closer to zero (L-shaped distribution) (Figure 5). This pattern was also seen in A. serrulatus (SSD $=0.004$, $p>0.05$ ) and A. japonicus (SSD $=0.032, p>0.05$ ) (Figure 5).

TABLE 6. Haplotype compositions and summary of molecular diversity in Acetes indicus collected in this study

\begin{tabular}{|c|c|c|c|c|c|c|c|c|c|c|c|c|}
\hline \multirow{2}{*}{$\begin{array}{l}\text { Haplo- } \\
\text { type }\end{array}$} & \multicolumn{11}{|c|}{ Sampling Locations* } & \multirow[b]{2}{*}{ Total } \\
\hline & SGT & BPL & $\mathrm{BL}$ & KK & KG & TR & SKC & TKR & PSETT & PKKP & SGK & \\
\hline ai1 & 7 & 7 & 6 & & & 3 & 6 & 5 & 1 & 4 & 5 & 44 \\
\hline ai2 & & & & & & & & & 1 & & & 1 \\
\hline ai3 & & & & & & & & & 1 & & & 1 \\
\hline ai4 & & & 1 & 5 & 6 & & & & 3 & & & 15 \\
\hline ai5 & & & & & & & & & 1 & & & 1 \\
\hline ai6 & & & & & & & & & 1 & & & 1 \\
\hline ai7 & 1 & & & & & & & & & & & 1 \\
\hline ai8 & & & & & & & 1 & 1 & & & & 2 \\
\hline ai9 & & & & & & 1 & & & & & & 1 \\
\hline ai10 & & & & & & 1 & & & & & & 1 \\
\hline ai11 & & & & & & & & & & 1 & & 1 \\
\hline$n$ & 8 & 7 & 7 & 5 & 6 & 5 & 7 & 6 & 8 & 5 & 5 & 69 \\
\hline$S$ & 1 & 0 & 45 & 0 & 0 & 2 & 1 & 1 & 47 & 1 & 0 & 50 \\
\hline$N_{h a p}$ & 2 & 1 & 2 & 1 & 1 & 3 & 2 & 2 & 6 & 2 & 1 & 11 \\
\hline$h$ & 0.2500 & 0.0000 & 0.2857 & 0.0000 & 0.0000 & 0.7000 & 0.2857 & 0.3333 & 0.8929 & 0.4000 & 0.0000 & 0.5516 \\
\hline$\pi$ & 0.0005 & 0.0000 & 0.02323 & 0.0000 & 0.0000 & 0.0015 & 0.0005 & 0.0006 & 0.0450 & 0.0007 & 0.0000 & 0.0312 \\
\hline
\end{tabular}

*Abbreviations for sampling locations: refer to Table 1

$n$ : number of sequences; $S$ : number of segregating sites; $N_{\text {hap }}:$ number of haplotypes; $h$ : haplotype diversity; and $\pi$ : nucleotide diversity. 
TABLE 7. Haplotype compositions and summary of molecular diversity in Acetes serrulatus collected in this study

\begin{tabular}{|c|c|c|c|c|c|c|c|c|c|}
\hline \multirow{2}{*}{ Haplotype } & \multicolumn{8}{|c|}{ Sampling locations* } & \multirow{2}{*}{ Total } \\
\hline & SGT & BPL & $\mathrm{BL}$ & SKC & TKR & TR & PKKP & SGK & \\
\hline as1 & 2 & 3 & 3 & 4 & 1 & 2 & 3 & 1 & 19 \\
\hline as2 & 3 & 4 & 2 & 1 & & & 1 & & 11 \\
\hline as3 & & 1 & & & & & & & 1 \\
\hline as 4 & 1 & & & & & & & & 1 \\
\hline as 5 & 1 & & & & & & & & 1 \\
\hline as6 & 1 & & & & & & & & 1 \\
\hline as7 & 1 & 1 & & & & & & & 2 \\
\hline as8 & 1 & 1 & & 1 & 1 & 1 & & & 5 \\
\hline as9 & & & 1 & & & & & & 1 \\
\hline as 10 & & & & & 1 & & & & 1 \\
\hline as11 & & & & & & 1 & & & 1 \\
\hline as 12 & 1 & & & & & & & & 1 \\
\hline as 13 & 1 & & & & & & & & 1 \\
\hline as14 & 1 & & & & & & & & 1 \\
\hline as 15 & 1 & & & & & & & & 1 \\
\hline as 16 & & 1 & & & & & & & 1 \\
\hline as 17 & & 1 & & & & & & & 1 \\
\hline as 18 & & 1 & & & & & & 1 & 2 \\
\hline as 19 & & & 1 & & & & & & 1 \\
\hline as 20 & & & 1 & & & & & & 1 \\
\hline as 21 & & & & 1 & & & & & 1 \\
\hline as 22 & & & & & 1 & & & & 1 \\
\hline as 23 & & & & & 1 & & & & 1 \\
\hline as 24 & & & & & & 1 & & & 1 \\
\hline as 25 & & & & & 1 & & & & 1 \\
\hline as 26 & & 1 & & & & & & & 1 \\
\hline as 27 & & 1 & & & & & & & 1 \\
\hline as 28 & & & & & & & 1 & & 1 \\
\hline as 29 & & & & & & & & 1 & 1 \\
\hline as 30 & & & & & & & & 1 & 1 \\
\hline as31 & & & & & & & & 1 & 1 \\
\hline $\mathrm{n}$ & 14 & 15 & 8 & 7 & 6 & 5 & 5 & 5 & 65 \\
\hline$S$ & 17 & 15 & 4 & 3 & 8 & 4 & 3 & 6 & 60 \\
\hline$N_{\text {hap }}$ & 11 & 10 & 5 & 4 & 6 & 4 & 3 & 5 & 31 \\
\hline$h$ & 0.9560 & 0.9143 & 0.8571 & 0.7143 & 1.0000 & 0.9000 & 0.7000 & 1.0000 & 0.8856 \\
\hline$\pi$ & 0.0062 & 0.0049 & 0.0021 & 0.0019 & 0.0052 & 0.0029 & 0.0025 & 0.0047 & 0.0042 \\
\hline
\end{tabular}

*Abbreviations for sampling locations: refer to Table 1

$n$ : number of sequences; $S$ : number of segregating sites; $N_{\text {hap }}$ : number of haplotypes; $h$ : haplotype diversity; and $\pi$ : nucleotide diversity 
TABLE 8. Haplotype compositions and summary of molecular diversity in Acetes japonicus collected in this study

\begin{tabular}{ccccc}
\hline \multirow{2}{*}{ Haplotype } & \multicolumn{3}{c}{ Sampling locations* } & \multirow{2}{*}{ Total } \\
\cline { 2 - 4 } & KK & KG & TBHG & \\
\hline aj1 & 1 & 3 & 2 & 6 \\
aj2 & 1 & 2 & 4 & 7 \\
$n$ & 2 & 5 & 6 & 13 \\
$S$ & 1 & 1 & 1 & 1 \\
$N_{\text {hap }}$ & 2 & 2 & 2 & 2 \\
$h$ & 1.0000 & 0.6000 & 0.5330 & 0.5386 \\
$\pi$ & 0.0018 & 0.0011 & 0.0010 & 0.0010 \\
\hline
\end{tabular}

*Abbreviations for sampling locations: refer to Table 1

$n$ : number of sequences; $S$ : number of segregating sites; $N_{\text {hap }}$ : number of haplotypes;

$h$ : haplotype diversity; and $\pi$ : nucleotide diversity

TABLE 9. Haplotype compositions and summary of molecular diversity in Acetes sibogae collected in this study

\begin{tabular}{cccc}
\hline \multirow{2}{*}{ Haplotype } & \multicolumn{2}{c}{ Sampling locations* } & Total \\
\cline { 2 - 3 } & SGKB & KS & 11 \\
\hline asi1 & 5 & 6 & 1 \\
asi2 & 1 & - & 12 \\
$n$ & 6 & 6 & 52 \\
$S$ & 52 & 0 & 2 \\
$N_{\text {hap }}$ & 2 & 1 & 0.1670 \\
$h$ & 0.3330 & 0.0000 & 0.0157 \\
$\pi$ & 0.0314 & 0.0000 & \\
\hline
\end{tabular}

*Abbreviations for sampling locations: refer to Table 1

$n$ : number of sequences; $S$ : number of segregating sites; $N_{\text {hap }}$ : number of haplotypes;

$h$ : haplotype diversity; and $\pi$ : nucleotide diversity

TABLE 10. Analysis of Molecular Variance (AMOVA) for Acetes indicus, A. serrulatus, A. japonicus and A, sibogae

\begin{tabular}{|c|c|c|c|c|c|c|c|}
\hline Analysis & Source of variation & d.f. & $\begin{array}{l}\text { Sum of } \\
\text { Squares }\end{array}$ & $\begin{array}{c}\text { Variance } \\
\text { Components }^{2}\end{array}$ & $\begin{array}{c}\text { Percentage of } \\
\text { Variation }\end{array}$ & $\begin{array}{c}\text { Fixation } \\
\text { index }\left(\Phi_{\mathrm{ST}}\right)\end{array}$ & $P$ value \\
\hline \multirow[t]{3}{*}{ Acetes indicus } & Among populations (Va) & 10 & 721.343 & 10.97601 & 75.77 & 0.75768 & $0.00000 \pm 0.00000$ \\
\hline & Within populations $(\mathrm{Vb})$ & 58 & 203.601 & 3.51036 & 24.23 & & \\
\hline & & 68 & 924.943 & 14.48637 & & & \\
\hline \multirow{3}{*}{$\begin{array}{l}\text { Acetes indicus } \\
\text { (without } \mathrm{KK}, \mathrm{KG} \\
\text { and PSETT }{ }^{1} \text { ) }\end{array}$} & Among populations $(\mathrm{Va})$ & 7 & 6.902 & -0.02362 & -2.13 & -0.02129 & $0.59881 \pm 0.00491$ \\
\hline & Within populations ( $\mathrm{Vb}$ ) & 42 & 47.586 & 1.13299 & 102.13 & & \\
\hline & & 49 & 54.488 & 1.10937 & & & \\
\hline \multirow{3}{*}{$\begin{array}{l}\text { Acetes indicus } \\
\text { (clade ai-I and } \\
\text { ai-II) }\end{array}$} & Among clade (Va) & 1 & 573.519 & 22.37565 & 99.19 & 0.99188 & $0.00000 \pm 0.00000$ \\
\hline & Within clade $(\mathrm{Vb})$ & 67 & 12.278 & 0.18326 & 0.81 & & \\
\hline & & 68 & 585.897 & 22.55891 & & & \\
\hline \multirow[t]{3}{*}{ Acetes serrulatus } & Among populations (Va) & 7 & 7.164 & -0.02252 & -1.91 & -0.01912 & $0.78921 \pm 0.00420$ \\
\hline & Within populations $(\mathrm{Vb})$ & 57 & 68.437 & 1.20065 & 101.91 & & \\
\hline & & 64 & 75.601 & 1.17812 & & & \\
\hline \multirow[t]{3}{*}{ Acetes japonicus } & Among populations (Va) & 2 & 0.198 & -0.05137 & -20.28 & -0.20285 & $0.76317 \pm 0.00416$ \\
\hline & Within populations $(\mathrm{Vb})$ & 10 & 3.046 & 0.30462 & 120.28 & & \\
\hline & & 12 & 3.244 & 0.25325 & & & \\
\hline \multirow[t]{3}{*}{ Acetes sibogae } & Among populations (Va) & 1 & 4.763 & 0.00000 & 0.00 & 0.00000 & $1.00000 \pm 0.00000$ \\
\hline & Within populations $(\mathrm{Vb})$ & 10 & 47.631 & 4.76314 & 100.00 & & \\
\hline & & 11 & 52.395 & 4.76314 & & & \\
\hline
\end{tabular}

${ }^{1}$ Sampling location, $\mathrm{KK}=$ Kuala Kurau, $\mathrm{KG}=$ Kuala Gula, PSETT $=$ Portuguese Settlement

${ }^{2} \mathrm{Va}, \mathrm{Vb}, \mathrm{Vc}$ are the associate covariance components 


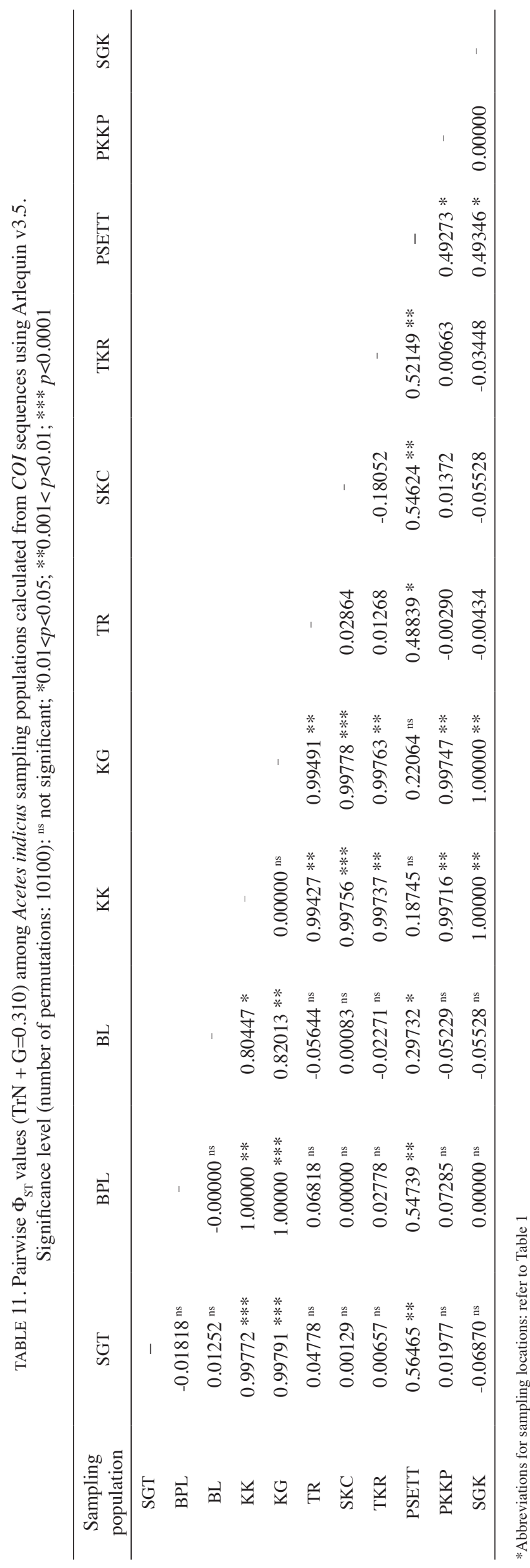


TABLE 12. Neutrality statistics (Tajima's $D$, Fu's $F$, Fu and Li's $D^{*}$ and $F^{*}, R_{2}$ ), sum of square deviation (SSD) and Harpending's Raggedness index $(r)$ were reported as well. Significance level: $* 0.01<p<0.05 ; * * 0.001<p<0.01 ; * * * p<0.001$; ${ }^{\text {ns }}$ not significant

\begin{tabular}{lccccccc}
\hline & Tajima's $D$ & Fu's Fs & Fu and Li's $D^{*}$ & Fu and Li's $F^{*}$ & $R_{2}$ & $S S D$ & $r$ \\
\hline A. indicus, pooled & $2.7155^{\mathrm{ns}}$ & $15.6730^{\mathrm{ns}}$ & $1.4841^{\mathrm{ns}}$ & $2.0928^{\mathrm{ns}}$ & $0.1715^{\mathrm{ns}}$ & 0.1116 & 0.2302 \\
A. indicus $_{\text {, Clade ai-I }}$ & $-2.1066^{* *}$ & $-8.940^{* * *}$ & $-3.4682^{* *}$ & $-3.5615^{* *}$ & $-0.0460^{*}$ & 0.0051 & 0.2618 \\
A. indicus, Clade ai-II & $-1.0486^{\mathrm{ns}}$ & $-0.1260^{\mathrm{ns}}$ & $-0.0627^{\mathrm{ns}}$ & $-0.3736^{\mathrm{ns}}$ & $0.1075^{* * *}$ & 0.0399 & 0.6075 \\
A. serrulatus & $-2.0787^{* *}$ & $-31.7964^{* * *}$ & $-3.5228^{* *}$ & $-3.5664^{* *}$ & $0.0314^{* * *}$ & 0.0041 & 0.0631 \\
A. japonicus & $1.4754^{\mathrm{ns}}$ & $1.2350^{\mathrm{ns}}$ & $0.7324^{\mathrm{ns}}$ & $1.0368^{\mathrm{ns}}$ & $0.2692^{\mathrm{ns}}$ & 0.0318 & 0.2959 \\
A. sibogae & $-2.2821^{* * *}$ & $11.772^{\mathrm{ns}}$ & $2.8994^{* * *}$ & $-3.1207^{* * *}$ & $0.2764^{\mathrm{ns}}$ & $0.0403^{*}$ & 0.7500 \\
\hline
\end{tabular}
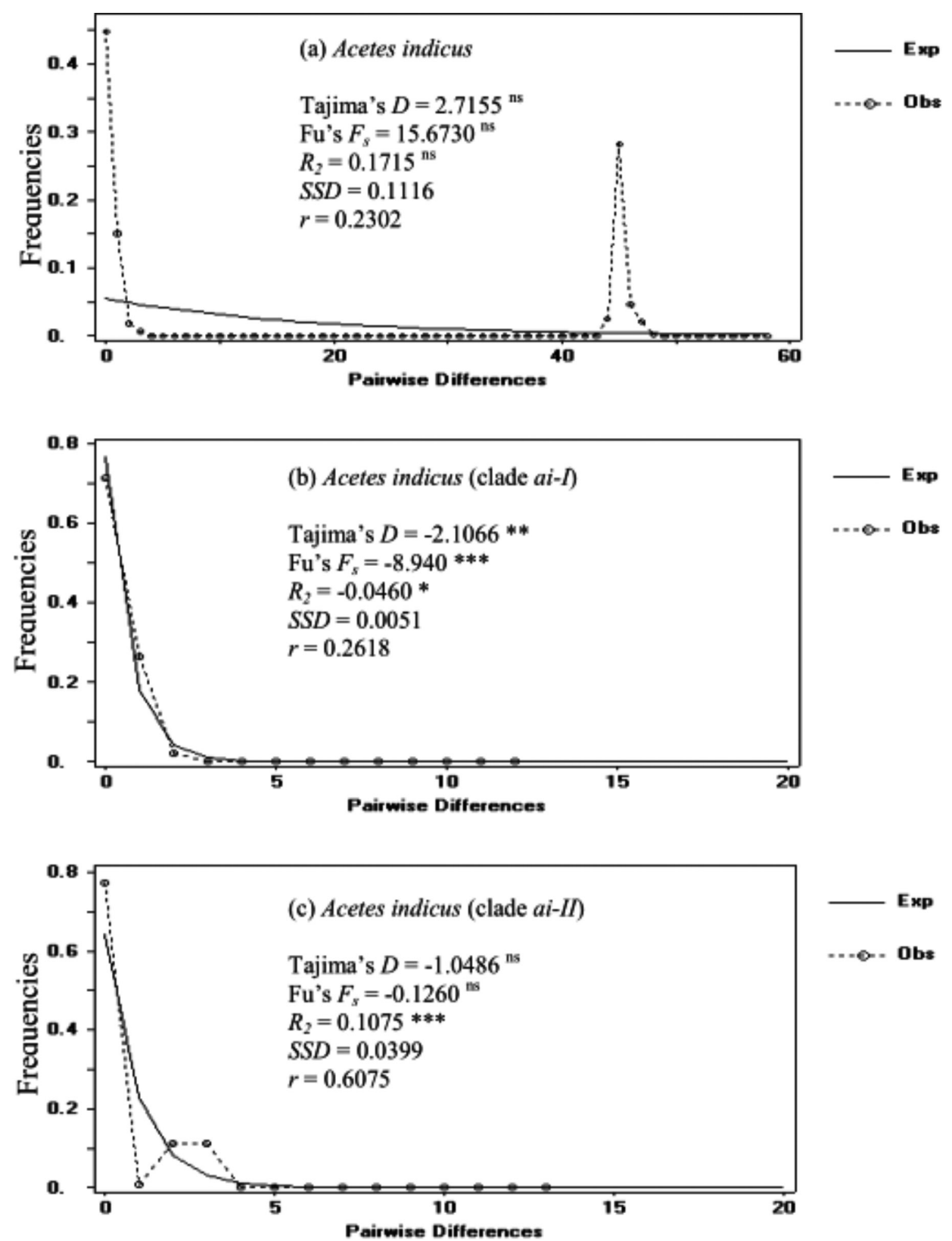

FIGURE 5. Mismatch distribution based on COI sequence from (a) A. indicus, (b) A. indicus, clade ai-I, and (c) A. indicus, clade ai-II. The graph represents the observed mismatch distribution from segregating sites of the aligned $\mathrm{COI}$ sequences. Dotted lines indicate the observed (Obs) distribution of mismatches, and solid lines show the expected (Exp) distribution under an expansion model. The numbers of pairwise differences are given on the horizontal axis and their frequencies on the vertical axis 

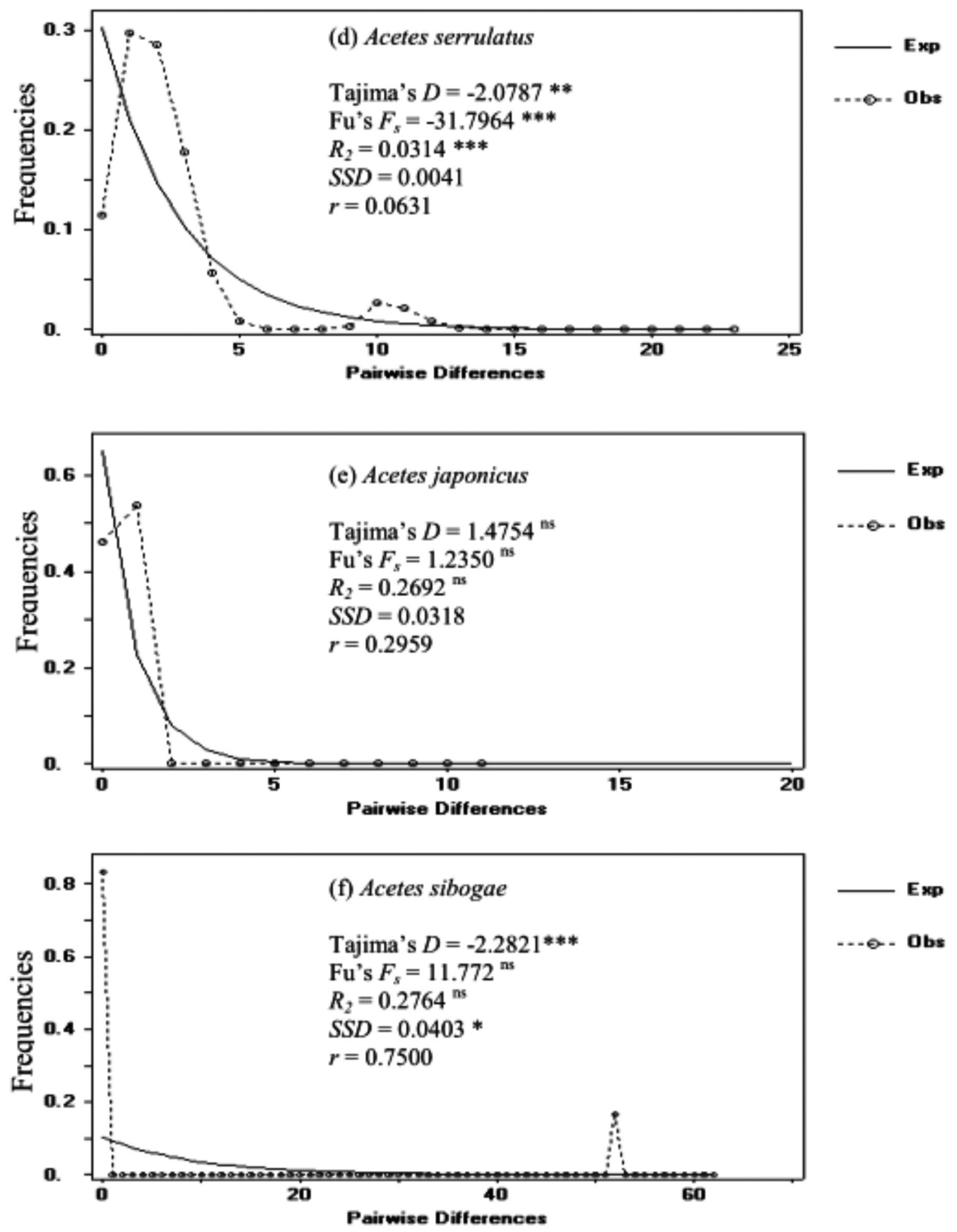

FIGURE 5 (continuation). Mismatch distribution based on COI sequence from (d) A. serrulatus, (e) A. japonicus, and (f) A. sibogae. The graph represents the observed mismatch distribution from segregating sites of the aligned COI sequences. Dotted lines indicate the observed distribution of mismatches, and solid lines show the expected distribution under an expansion model. The numbers of pairwise differences are given on the horizontal axis and their frequencies on the vertical axis

\section{DISCUSSION}

\section{COI SEQUENCE VARIATION}

High $\mathrm{A}+\mathrm{T}$ content and positional biases, for example, slight bias against cytosine (17.3\%) in the first position, in favour of thymine $(45.7 \%)$ in the second position and substantial bias against guanine $(2.9 \%)$ in the third position of mitochondrial $C O I$ gene fragment was found in all Acetes indicus, A. serrulatus, A. japonicus and A. sibogae individuals analysed in this study (Table 4). This pattern of base composition is similar to the COI gene region sequences in other groups of crustaceans, including Raymunida (Macpherson \& Machordom 2001), Portunidae (Chu et al. 1999; Lai et al. 2010; Pfeiler et al. 2005), Alpheidae (Williams \& Knowlton 2001; Williams et al. 2002, 2001), Gammaridae (Meyran et al. 1997), as well as some penaeid shrimp species (Baldwin et al. 1998; Maggioni et al. 2001; Quan et al. 2004; Tong et al. 2000; Zitari-Chatti et al. 2009).

With respect to the amino acid substitutions, $\mathrm{COI}$ is considered to be one of the most conservative genes in the mitochondrial genome (Black et al. 1997), thus only three amino acids substitution were detected in this study. The translation of the 552 bp of COI gene fragment 
resulted in a sequence of 184 amino acids without in-frame stop codons or indels. Together with the patterns of base composition and base substitutions as discussed above, these observations showed that the $\mathrm{COI}$ gene fragment amplified in this study was not a nuclear mitochondrial pseudogenes (Numts) (Bensasson et al. 2001; Song et al. 2008; Zhang \& Hewitt 1996) that have been reported in crustaceans, including in the snapping shrimp, Alpheus (Williams \& Knowlton 2001; Williams et al. 2002).

\section{INTERSPECIFIC VARIATION OF ACETES SPECIES}

From the phylogenetic trees inferred from the COI sequence (Figures $2 \& 3$ ), it is evident that four distinct clades could be clearly identified using NJ, MP, ML and BI. All clades were monophyletic and supported by high BS and PP that corresponded with the four different Acetes species identified morphologically. This indicates that the COI molecular trees and species identification based on morphological characters provided by Omori (1975) and Wong (2013) are congruent. In addition, the aligned 552 bp of COI sequence showed a divergence range of 14.69$20.47 \%$ among the four Acetes species in this study (Table $5)$. This level of sequence divergence is similar to those reported in other shrimp genera such as Penaeus (8.024.0\%; Baldwin et al. 1998) and Metapenaeus (6.1-19.9\%; Tong et al. 2000), but is higher than those of the portunid sister groups (2-7\%; Lai et al. 2010).

\section{INTRASPECIFIC VARIATION OF ACETES SPECIES}

Acetes indicus For the pooled samples, the moderate haplotype diversity and high nucleotide diversity is a good reflection of the abundance of this species within the west coast of Peninsular Malaysia (Table 6). This species was found in most sampling sites and had previously been reported to occur from the north-western region to the south of Peninsular Malaysia (Amani et al. 2011c; Amin et al. 2011, 2009a, 2009b, 2009c, 2009d; Fernandez-Leborans et al. 2009; Oh et al. 2010), mainly from in-shore catches. In this study, $A$. indicus was also caught from off-shore catches. However, the actual geographical range of dispersal of $A$. indicus is unknown.

The moderate haplotype diversity and high nucleotide diversity is also indicative of past evolutionary processes (Table 6), suggesting either secondary contact between historically isolated populations or stable populations with large, long term-effective population sizes (Grant \& Bowen 1998). The secondary contact of historically isolated populations could have occurred due to the fluctuation of sea-levels in the regions around the Sunda and Sahul shelves in which low sea levels led to the formation of large land masses which partly isolated the Indian Ocean from the West Pacific and enclosed the South China Sea, Sulu Sea and Sulawesi Sea (Voris 2000). The central part of Indo-West Pacific area is reported as the geographical range of this species (Chan 1998; Holthius 1980; Omori 1975; Xiao \& Greenwood 1993). The receding sea levels could have temporarily isolated the $A$. indicus populations occurring in these regions and restricted gene flow among the populations. Thus, the isolated A. indicus populations could have evolved separately and secondary contact occurred only during subsequent increase of the sea levels. Using the minimum and maximum nucleotide divergence between the two distinct clades of A. indicus (ai-I and ai-II) seen in the NJ tree (Figure 2) and the $1.40-3.00 \%$ per million years for $\mathrm{COI}$ divergence rates for decapod crustaceans on K2P distances (Table 5), we found a 2.98-6.39 million years ago (MYA) split between the clades indicating an early Pliocene to late Miocene divergence, thus supporting the geographical isolation episode mentioned earlier. The mixture of haplotypes found in the Bagan Lipas and the Portuguese Settlement populations may reflect secondary contact between the two clades (Table 6).

When the two clades were analysed separately, low haplotype diversity and nucleotide diversity were observed (Table 6). This pattern of low genetic diversity often reflects recent events of population bottleneck or founder effects by a single or a few mtDNA lineages (Grant \& Bowen 1998). The NJ tree showed two deep clades for $a i-I$ and $a i-I I$ (Figure 2), but shallow phylogeny within these two clades suggests population expansion after bottleneck (Slatkin \& Hudson 1991). This hypothesis was also supported by the unimodal mismatch distribution, the non-significant value of sum of squared deviation (SSD) and Harpending's raggedness index $(r)$ and the negative values of Tajima's $D$ and Fu's $F_{S}$ (Aris-Brosou \& Excoffier 1996; Fu, 1997; Rand 1996; Tajima 1989) (Table 12; Figure 5a-5c).

The L-shaped mismatch distribution has been reported in other shrimp species indicating population expansion from a smaller initial population and recent bottleneck events (Frankham et al. 2002; Li et al. 2009; Pellerito et al. 2009; Rogers \& Harpending 1992; Roldan et al.2009). As many as 10 major Pleistocene sea-level fluctuation events, during which the Sunda Shelf (including the Straits of Malacca) was exposed had occurred with the latest being the last-glacial maximum, around 18000-20000 years ago during which the sea level dropped to about $120 \mathrm{~m}$ below the present level in Southeast Asia (Hanebuth et al. 2000; Pillans et al. 1998). These events could have caused local extinctions in the sampling area of this study. Based on the $\tau$ value computed using Arlequin and 1.4-3.0\% mutation rates (Tables 5, $10 \& 11$ ), the estimates of the time since the most recent sudden population expansion for these two clades fall within the range of 97000-45000 years ago, coinciding with the Pleistocene era sea fluctuations. Therefore, for A. indicus, the genetic diversity seems to suggest secondary contact between historically isolated populations (Wong 2013).

Acetes serrulatus A high haplotype diversity and low nucleotide diversity were observed for this species (Table 7). Similar to A.indicus, the high haplotype diversity could be due to the occurrence of this species in both in- and offshore catches of a relatively large region from the central to the south of the west coast of Peninsular Malaysia. 
Previous studies had only reported their occurrence along in-shore areas of the south of the west coast (Amin et al. 2011, 2009d; Oh et al. 2011). The high haplotype diversity and low nucleotide diversity combination usually suggests a population that had undergone population bottlenecks followed by rapid population growth and accumulation of mutations (Avise et al. 1984; Grant \& Bowen 1998), which have also been noted in other marine species (Chen et al. 2004; Daemen et al. 2001; Kong et al. 2010; Liu et al. 2008; Maggio et al. 2009; Pellerito et al. 2009; Stockley et al. 2005).

The low nucleotide diversity reflects low genetic divergence among A. serrulatus individuals (Table 7). As reported for A. indicus, the shallow phylogeny of the $\mathrm{NJ}$ tree (Figure 2) is consistent with a population expansion event after a period of low effective population sizes caused by bottlenecks or founder effects (Slatkins \& Hudson 1991). Negative and significant values of Tajima's $D$ and Fu's $F_{S}$ and significant $R_{2}$ indicate population expansion (Aris-Brosou \& Excoffier 1996; Fu 1997; Ramos-Onsins \& Rozas 2002; Rand 1996; Tajima 1989) (Table 12; Figure 5). The star-like radiating pattern of the haplotype network (Figure 4), unimodal mismatch distribution, and low nonsignificance of Harpending's Raggedness index $(r)$ further supports a hypothesis of recent population expansion (Rogers \& Harpending 1992; Slatkin \& Hudson 1991). There is an excess of rare mutations seen here as excess in singletons suggests accumulation of mutations during the rapid population growth (Avise et al. 1984; Jorde et al. 2001; Rogers \& Harpending 1992; Ramos-Onsins \& Rozas 2002; Slatkins \& Hudson 1991). As in A. indicus (Tables $5,10 \& 11)$, A. serrulatus appears to have also undergone late-Pleistocene expansion, due to the fluctuating sea levels (Wong 2013). The estimates of the time since the most recent population expansion event for $A$. serrulatus took place approximately 61000-28000 years ago, coinciding with rising sea levels during the late Pleistocene (Geyh et al. 1979; Hanebuth et al. 2000; Voris 2000).

Acetes japonicus AND Acetes sibogae The presence of these two species from the sampling sites in the northern waters of the west coast of Peninsular Malaysia is similar to that reported by Amani et al. (2011a, 2011b, 2011c), Amin et al. (2011, 2010, 2009c, 2009d), Arshad et al. (2012), Fernandez-Leborans et al. (2009), Hanamura (2007) and Panthansali (1966). However, we did not detect any of these two species at the southern region of the west coast during the sampling period of our study (Wong 2013; Wong et al. 2015). As such, with only three sample populations for A. japonicus and two populations for A. sibogae, demographic analyses and genetic diversity of these species were not conducted in detail to avoid inaccurate and biased reporting (Tables 8-10 \& 12).

\section{CRYPTIC DIVERSITY AND ITS IMPLICATIONS}

Although morphologically defined species was congruent with the mtDNA in this study, it does not reveal all the variations that are present genetically, especially in the cryptic diversity possibly present in A. indicus and $A$. sibogae. Evidence for cryptic diversity comes from the extent of the genetic distance seen between clades within these two species (Wong 2013). Sequence divergence between clades ai-I and ai-II (8.94\%) and clades asi-I and asi-II (10.30\%) are lower than interspecific COI divergences of Acetes species in the current study (Table 5). Divergence values of similar magnitude have been noted in cryptic or sibling species (i.e. morphologically indistinguishable, but genetically distinct) of other decapod crustaceans (Bickford et al. 2007; Knowlton 1986; Pfenninger \& Schwenk 2007). In particular, studies have reported a 6-8\% divergence between two cryptic species of the kuruma shrimp, Penaeus japonicus (Tsoi et al. 2007, 2005), a 2-5\% divergence between two sibling alpheid species, Alpheus angulatus and A. armillatus (Mathews et al.2002), two morphologically indistinguishable clades within Fenneropenaus (Penaeus) merguiensis with an average divergence of $5 \%$ (Hualkasin et al. 2003) and 2-7\% genetic divergence among sister groups of Portunus spp. (Lai et al. 2010).

Further support for cryptic diversity is shown by the COI haplotypes of A. indicus and A. sibogae which grouped into two disconnected statistical parsimony network at the $95 \%$ connection limit (Figure 4). As proposed by Chen et al. (2010) and Hart and Sunday (2007), statistical parsimony networks that are separated by more than the parsimony connection limit would indicate the presence of cryptic species. Hence, the high sequence divergence values and the disconnected parsimony network for Acetes suggest that cryptic taxa may be present in A. indicus and A. sibogae (Wong 2013). Cryptic species require special consideration in conservation planning especially for highly exploited resources. The likely presence of cryptic complexes within these Acetes species implies that more in-depth knowledge of location boundaries (if any) and other biotic and abiotic factors for each species would need to be considered for conservation efforts to ensure the long term sustainability of the Acetes fishing industry. Fishery activities beyond sustainable limits coupled with the presence of unknown cryptic species can lead to the disappearance of these resources (Thorpe et al. 2000).

Another implication of cryptic diversity is that previous reports of the life cycles of Acetes spp. may not reflect the true biological nature of these species, since those reports were based solely on morphological data (Amani et al. 2011a, 2011b, 2011c; Amin et al. 2011, 2010, 2009a, 2009b, 2009c, 2009d, 2008; Arshad et al. $2012,2008,2007)$ which is unable to differentiate among the cryptic complexes. Our study recommends that a thorough and detailed investigation should be carried out throughout the year with more sampling sites for both in- and offshore Acetes populations in order to elucidate the actual distribution and life cycles of each cryptic complex. This should also be coupled with nuclear gene studies (Wong 2013). Since mtDNA has a higher rate of evolution and thus more mutations than nuclear genes, it 
is essential to have genealogical data from nuclear genes, which are inherited from both parents, to establish the status of these two clades. These studies would provide a better management plan for sustainable fishing over time.

In conclusion, this study presents evidence of the molecular phylogenetic relationships among four major Acetes species sampled from the west coast of Peninsular Malaysia. The four species were found to vary considerably for haplotype and nucleotide diversity, with A. indicus and $A$. serrulatus having different demographic histories. Furthermore, the observation of two clades within the $A$. indicus and $A$. sibogae lineages, with relatively high levels of intraspecific divergence, suggests that cryptic diversity may occur in these two taxa.

\section{ACKNOWLEDGEMENTS}

This study was supported by a UTAR Postgraduate Research Fund (6202/W01) to Wong B.Y. The authors would also like to express their gratitude to Mr. Chia B.L. for providing the off-shore samples used in this study.

\section{REFERENCES}

Allendorf, F.W. \& Luikart, G. 2006. Conservation and the Genetics of Populations. Oxford: Blackwell Publishing, MA.

Altschul, S.F., Gish, W., Miller, W., Myers, E.W.\& Lipman, D.J. 1990. Basic local alignment search tool. Journal of Molecular Biology 215(3): 403-410.

Amani, A.A., Arshad, A., Amin, S.M.N. \& Aziz, N.A.A. 2011a. Catch composition of a set bag net used for Acetes trapping in the estuarine waters of Kedah, Peninsular Malaysia. Journal of Fisheries and Aquatic Science 6(3): 279-284.

Amani, A.A., Amin, S.M.N., Arshad, A. \& Rahman, M.A. 2011 b. Population dynamics of sergestid shrimps Acetes japonicus in the estuary of Tanjung Dawai, Kedah, Malaysia. Journal of Fisheries and Aquatic Science 6(7): 751-760.

Amani, A.A., Amin, S.M.N. \& Arshad, A. 2011c. Stomach contents of sergestid shrimp Acetes japonicus from the estuary of Tanjung Dawai, Peninsular Malaysia. Journal of Fisheries and Aquatic Science 6(7): 771-779.

Amin, S.M.N.,Arshad,A., Siraj, S.S. \& Bujang, J.S. 2011. Update on the species composition and distribution of sergestide shrimps (Acetes spp.) in Malaysian waters. Journal of Fisheries and Aquatic Science 6(7): 761-770.

Amin, S.M.N., Arshad, A., Siraj, S.S. \& Japar, S.B. 2010. Reproductive seasonality and maturation of the sergestid shrimp, Acetes japonicus (Decapoda: Sergestidae) in coastal waters of Malacca, Peninsular Malaysia. African Journal of Biotechnology 9(45): 7747-7752.

Amin, S.M.N., Arshad, A., Bujang, J.S. \& Siraj, S.S. 2009a. Age structure, growth, mortality and yield-per-recruit of sergestid shrmp, Acetes indicus (Decapoda: Sergestidae) from the coastal waters of Malacca, Peninsular Malaysia. Journal of Applied Sciences 9(5): 801-814.

Amin, S.M.N., Arshad, A., Bujang, J.S., Siraj, S.S. \& Goddard, S. 2009b. Reproductive biology of the sergestid shrimp Acetes indicus (Decapoda: Sergestidae) in coastal waters of Malacca, Peninsular Malaysia. Zoological Studies 48(6): 753-760.

Amin, S.M.N., Arshad, A., Siraj, S.S. \& Japar, S.B. 2009c. Population structure, growth, mortality and yield per recruit of sergestid shrimp, Acetes japonicus (Decapoda: Sergestidae) from the coastal waters of Malacca, Peninsular Malaysia. Indian Journal of Marine Science 38(1): 57-68.

Amin, S.M.N., Arshad, A., Siraj, S.S. \& Bujang, J.S. 2009d. Population structure, growth and length - weight relationship of sergestid shrimps (Acetes spp.) from the coastal waters of Malacca, Peninsular Malaysia. Sains Malaysiana 38(2): 159-169.

Amin, S.M.N., Arshad, A., Zainal, Z., Idris, M.H., Siraj, S.S. \& Japar, S.B. 2008. First distribution records of Acetes intermedius (Decapoda: Sergestidae) from the coastal waters of Bintulu, Sarawak: Population structure, length-weight and length-length relationship. Journal of Sustainability Science and Management 3(1): 74-83.

Aris-Brosou, S. \& Excoffier, L. 1996. The impact of population expansion and mutation rate heterogeneity on DNA sequence polymorphism. Molecular Biology and Evolution 13(3): 494-504.

Arshad, A., Amin, S.M.N., Nuradiella, Y.L.Z., Cob, Z.C., Ara, R. \& Aziz, D. 2012. Population characteristics of Acetes japonicus from the Kedah coastal waters of Peninsular Malaysia. Journal of Fisheries and Aquatic Science 7(2): 162-172.

Arshad, A., Amin, S.M.N., Yu, G.T., Oh, S.Y., Bujang, J.S. \& Ghaffar, M.A. 2008. Population characteristics, lengthweight and length-length relationships of Acetes vulgaris (Decapoda: Sergestidae) in the coastal waters of Pontian, Johor, Peninsular Malaysia. Journal of Biological Sciences 8(8): 1298-1303.

Arshad, A., Amin, S.M.N., Siraj, S.S. \& Japar, S.B. 2007. New distribution records of sergestid shrimp, Acetes intermedius (Decapoda: Sergestidae) from Peninsular Malaysia with notes on its population characteristics. Journal of Biological Sciences 7(8): 1305-1313.

Avise, J., Neigel, J. \& Arnold, J. 1984. Demographic influences on mitochondrial DNA lineage survivorship in animal populations. Journal of Molecular Evolution 20(2): 99-105.

Baldwin, J.D., Bass, A.L., Bowen, B.W. \& Clark, W.H. 1998. Molecular phylogeny and biogeography of the marine shrimp Penaeus. Molecular Phylogenetics and Evolution 10(3): 399-407.

Bensasson, D., Zhang, D.X., Hartl, D.L. \& Hewitt, G.M. 2001. Mitochondrial pseudogenes: Evolution's misplaced witnesses. Trends in Ecology and Evolution 16(6): 314-321.

Bickford, D., Lohman, D.J., Sodhi, N.S., Ng, P.K.L., Meier, R., Winker, K., Ingram, K.K. \& Das, I. 2007. Cryptic species as a window on diversity and conservation. Trends in Ecology \& Evolution 22(3): 148-155

Black, M.B., Halanych, K.M., Maas, P.A.Y., Hoeh, W.R., Hashimoto, J., Desbruyères, D., Lutz, R.A. \& Vrijenhoek, R.C. 1997. Molecular systematics of vestimentiferan tubeworms from hydrothermal vents and cold-water seeps. Marine Biology 130(2): 141-149.

Black. A.R. \& Dodson, S.I. 2003. Ethanol: A better preservation technique for Daphnia. Limnology and Oceanography: Methods 1: 45-50.

Bucklin, A. 2009. CMarz sample collection protocol. Census of Marine Zooplankton. CMarz Barcoding Association. (http://www.cmarz.org/barcode/protocols/barcode_CMarZ_ Sample_Protocol_jan06.html)

Camin, J. \& Sokal, R. 1965. A method for deducing branching sequences in phylogeny. Evolution 19(3): 311-326.

Carvalho, G.R. \& Hauser, L. 1994. Molecular genetics and the stock concept in fisheries. Reviews in Fish Biology and Fisheries 4(3): 326-350. 
Chan, T.Y. 1998. Shrimps and prawns. In FAO Species Identification Guide for Fishery Purposes. The Living Marine Resource of the Western Central Pacific, Vol.2.Cephalopds, Crustaceans, Holothurians and Sharks, edited by Carpenter, K.E. \& Niem, V.H. Rome: FAO.

Chen, C.A.,Ablan, M.C.A., Mcmanus, J.W., Bell,J.D., Tuan, V.S., Cabanban, A.S. \& Shao, K.T. 2004. Population structure and genetic variability of six bar wrasse (Thallasoma hardwicki) in Northern South China Sea revealed by mitochondrial control region sequences. Marine Biotechnology 6(4): 312326.

Chen, H., Strand, M., Norenburg, J.L., Sun, S., Kajihara, H., Chernyshev, A.V., Maslakova, S.A. \& Sundberg, P. 2010. Statistical parsimony networks and species assemblages in cephalotrichid nemerteans (nemertea). PLOS ONE 5(9): e12885.

Chu, K.H., Tong, J. \& Chan, T.Y. 1999. Mitochondrial cytochrome oxidase I sequence divergence in some Chinese species of Charybdis (Crustacea: Decapoda: Portunidae). Biochemical Systematics and Ecology 27(5): 461-468.

Clement, M., Posada, D. \& Crandall, K.A. 2000. TCS: A computer program to estimate gene genealogies. Molecular Ecology 9(10): 1657-1659.

Cook, B.D., Baker, A.M., Page, T.J., Grant, S.C., Fawcett, J.H., Hurwood, D.A. \& Hughes, J.M. 2006. Biogeographic history of an Australian freshwater shrimp, Paratya australiensis (Atyidae): The role life history transition in phylogeographic diversification. Molecular Ecology 15: 1083-1093.

Costa, F.O., deWaard, J.R., Boutillier, J., Ratnasingham, S., Dooh, R.T., Hajibabaei, M. \& Hebert, P.D. 2007. Biological identifications through DNA barcodes: The case of the Crustacea. Canadian Journal of Fisheries and Aquatic Sciences 64(2): 272-295.

Daeman, E., Cross, T., Ollevier, F. \& Volckaert, F.A.M. 2001. Analysis of the genetic structure of European eel (Anguilla anguilla) using microsattelite DNA and mtDNA markers. Marine Biology 139(4): 755-764.

Deshmukh, V.D. 1991. Utilisation of paste shrimp Acetes: A review. Marine Fisheries Information Service Technical Extension Series 110: 7-8.

Díaz-Viloria, N., Sánchez-Velasco, L. \& Perez-Enriquez, R. 2005. Inhibition of DNA amplification in marine fish larvae preserved in formalin. Journal of Plankton Research 27(8): 787-792.

DiStefano, R.J., Roell, M.J., Wagner, B.A. \& Decoske, J.J. 1994. Relative performances of four preservatives on fish and crayfish. Transactions of the American Fisheries Society 123: 817-823.

DOF. 2013. Annual Fisheries Statistics. Kuala Lumpur: Department of Fisheries Malaysia, Ministry of Agriculture.

Excoffier, L. \& Lischer, H.E.L. 2010. Arlequin suite ver 3.5: A new series of programs to perform population genetics analyses under Linux and Windows. Molecular Ecology Resources 10(3): 546-567.

Excoffier, L., Smouse, P.E. \& Quattro, J.M. 1992. Analysis of molecular variance inferred from metric distances among DNA haplotypes: Application to human mitochondrial DNA restriction data. Genetics 131(2): 479-491.

Felsenstein, J. 1985. Confidence limits on phylogenies: An approach using the bootstrap. Evolution 39(4): 783-791.

Felsenstein, J. 1981. Evolutionary trees from DNA sequences: A maximum likelihood approach. Journal of Molecular Evolution 17(6): 368-376.
Fernandez-Leborans, G., Hanamura, Y., Siow, R. \& Chee, P.E. 2009. Intersite epibiosis characterization on dominant mangrove crustacean species from Malaysia. Contributions to Zoology 78(1): 9-23.

Folmer, O., Black, M., Hoeh, W., Lutz, R. \& Vrijenhoek, R. 1994. DNA primers for amplification of mitochondrial cytochrome $c$ oxidase subunit I from diverse metazoan invertebrates. Molecular Marine Biology and Biotechnology 3(5): 294-299.

Frankham, R., Ballou, J.D. \& Briscoe, D.A. 2002. Introduction to Conservation Genetics. Cambridge: Cambridge University Press.

Fu, Y.X. 1997. Statistical tests of neutrality against population growth, hitchhiking and background selection. Genetics 147: 915-925.

García-Machado, E., Robainas, A., Espinosa, G., Oliva, M., Páez, J., Verdecia, N. \& Monnerot, M. 2001 . Allozyme and mitochondrial DNA variation in Cuban populations of the shrimp Farfantepenaeus notialis (Crustacea: Decapoda). Marine Biology 138(4): 701-707.

Gascuel, O. 1997. BIONJ: An improved version of the NJ algorithm based on a simple model of sequence data. Molecular Biology and Evolution 14(7): 685-695.

Geyh, M.A., Steif, H. \& Kudrass, H.R. 1979. Sea-level changes during the late Pleistocene and Holocene in the Strait of Malacca. Nature 278(5703): 441-443.

Grant, W.S. \& Bowen, B.W. 1998. Shallow population in deep evolutionary lineages of marine fishes: Insights from sardines and anchovies and lessons for conservation. Journal of Heredity 89(5): 415-426.

Guindon, S., Lethiec, F., Duroux, P. \& Gascuel, O. 2005.PHYML Online - a web server for fast maximum likelihood-based phylogenetic inference. Nucleic Acids Research 33(Suppl 2): W557-W559.

Hanamura, Y., Siow, R. \& Chee, P.E. 2007. Abundance and spatio temporal distributions of hyper benthic crustaceans in the Merbok and Matang mangroves estuaries, Malaysia. In Sustainable Production Systems of Aquatic Animals in Brackish Mangrove Areas (2005), edited by Nakamura K. Japan International Research Center for Agriculture Sciences (JIRCAS).

Hanebuth, T., Stattegger, K.\& Grootes, P.M. 2000. Rapid flooding of the Sunda Shelf: A late-glacial sea-level record. Science 288(5468): 1033-1035.

Harpending, H.C. 1994. Signature of ancient population growth in a low-resolution mitochondrial DNA mismatch distribution. Human Biology 66(4): 591-600.

Harrison, M.K. \& Crespi, B.J. 1999. Phylogenetics of cancer crabs (Crustacea: Decapoda: Brachyura). Molecular Phylogenetics and Evolution 12(2): 186-199.

Hart, M.W. \& Sunday, J. 2007. Things fall apart: Biological species form unconnected parsimony networks. Biology Letters 3(5): 509-512.

Hebert, P.D.N., Cywinska, A., Ball, S.L. \& deWaard, J.R. 2003. Biological identifications through DNA barcodes. Proceedings of the Royal Society London B 270(1512): 313-321.

Holthuis, L.B. 1980. FAO Species Catalogue Vol. 1. Shrimps and Prawns of the World: An Annotated Catalogue of Species of Interest to Fisheries. Rome: FAO Fisheries Synopsis. 125(1): 62-67.

Hualkasin, W., Sirimontaporn, P., Chotigeat, W., Querci, J. \& Phongdara, A. 2003. Molecular phylogenetic analysis of white prawns species and the existence of two clades in 
Penaeus merguiensis. Journal of Experimental Marine Biology and Ecology 296(1): 1-11.

Hudson, R.R. 1990. Gene genealogies and the coalescent process. Oxford Surveys in Evolutionary Biology 7: 1-44.

Huelsenbeck, J.P. \& Ronquist, F. 2001. MRBAYES: Bayesian inference of phylogenetic trees. Bioinformatics 17(8): 754755.

Hurvich, C.M. \& Tsai, C.L. 1989. Regression and time series model selection in small samples. Biometrika 76(2): 297-307.

Jarvis, J.P., Luedeman, J.K. \& Shier, D.R. 1983. Comments on computing the similarity of binary trees. Journal of Theoretical Biology 100(3): 427-433.

Job, S., Buu, D. \& Vincent, A. 2006. Growth and survival of the tiger tail seahorse, Hippocampus comes. Journal of the World Aquaculture Society 37(3): 322-327.

Jorde, L.B., Watkins, W.S. \& Bamshad, M.J. 2001. Population genomics: A bridge from evolutionary history to genetic medicine. Human Molecular Genetics 10(20): 2199-2207.

Khamnamtong, B., Klinbunga, S. \& Menasveta, P. 2009. Genetic diversity and geographic differentiation of the giant tiger shrimp (Penaeus monodon) in Thailand analyzed by mitochondrial COI sequences. Biochemical Genetics 47(12): 42-55.

Kimura, M. 1980. A simple method for estimating evolutionary rates of base substitutions through comparative studies of nucleotide sequences. Journal of Molecular Evolution 16(2): 111-120.

Knowlton, N. 1986. Cryptic and sibling species among the decapod crustacea. Journal of Crustacean Biology 6(3): 356-363.

Kong, X.Y., Li, Y.L., Shi, W. \& Kong, J. 2010. Genetic variation and evolutionary demography of Fenneropenaeus chinensis populations, as revealed by the analysis of mitochondrial control region sequences. Genetics and Molecular Biology 33(2): 379-389.

Lai, J.C.Y., Ng, P.K.L. \& Davie, P.J.F. 2010. A revision of the Portunus pelagicus (Linnaeus, 1758) species complex (Crustacea: Brachyura: Portunidae), with the recognition of four species. The Raffles Bulletin of Zoology 58(2): 199-237.

Li, Y.L., Kong, X.Y., Yu, Z.N., Kong, J., Ma, S. \& Chen, L.M. 2009. Genetic diversity and historical demography of Chinese shrimp Fenneropenaeus chinensis in Yellow Sea and Bohai Sea based on mitochondrial DNA analysis. African Journal of Biotechnology 8(7): 1193-1202.

Librado, P. \& Rozas, J. 2009. DnaSP v5: A software for comprehensive analysis of DNA polymorphism data. Bioinformatics 25(11): 1451-1452.

Liu, S.Y., Kokita, T. \& Dai, C.F. 2008. Population genetic structure of the neon damselfish (Pomacentrus coelestis) in the northwestern Pacific Ocean. Marine Biology 154(4): 745-753.

Longhurst, A.R. 1970. Crustacean resources. In The Fish Resources of the Oceans, edited by Gulland, J.A. FAO Fisheries Technical Paper No.97. Rome: FAO. pp. 252-305.

Machordom, A. \& Macpherson, E. 2004. Rapid radiation and cryptic speciation in squat lobsters of the genus Munida (Crustacea, Decapoda) and related genera in the South West Pacific: Molecular and morphological evidence. Molecular Phylogenetics and Evolution 33(2): 259-279.

Macpherson, E. \& Machordom, A. 2001. Phylogenetic relationships of species of Raymunida (Decapoda: Glatheidae) based on morphology and mitochondrial cytochrome oxidase sequences, with the recognition of four new species. Journal of Crustacean Biology 21(3): 696-714.
Maggio, T., Lo Brutto, S., Cannas, R., Deiana, A.M. \& Arculeo, M. 2009. Environmental features of deep-sea habitats linked to the genetic population structure of a crustacean species in the Mediterranean Sea. Marine Ecology 30(3): 354-365.

Maggioni, R., Rogers, A.D., Maclean, N. \& D'Incao, F. 2001. Molecular phylogeny of western atlantic Farfantepenaeus and Litopenaeus shrimp based on mitochondrial 16S partial sequences. Molecular Phylogenetics and Evolution 18(1): 66-73.

Mantel, N. 1967. The detection of disease clustering and a generalised regression approach. Cancer Research 27: 209-220.

Mathews, L.M., Schubart, C.D., Neigel, J.E. \& Felder, D.L. 2002. Genetic, ecological, and behavioural divergence between two sibling snapping shrimp species (Crustacea: Decapoda: Alpheus). Molecular Ecology 11(8): 1427-1437.

Meyran, J.C., Monnerot, M. \& Taberlet, P. 1997. Taxonmic status and phylogenetic relationships of some species of the genus Gammarus (Crustacea, Amphipoda) deduced from mitochondrial DNA sequence. Molecular Phylogenetics and Evolution 8(1): 1-10.

Nei, M. 1987. Molecular Evolutionary Genetics. New York: Columbia University Press.

Oh, S.Y., Arshad, A., Japar, S.B., Nor Azwady, A.A. \& Amin, S.M.N. 2011. Diet composition of sergestid shrimp Acetes serrulatus from the coastal waters of Kukup, Johor, Malaysia. Journal of Fisheries and Aquatic Science 6(7): 809-815.

Oh, S.Y., Arshad, A., Pang, S.P. \& Amin, S.N. 2010. Catch composition of estuarine set bag net fishery in the coastal area of Pontian, Johor, Peninsular Malaysia. Journal of Biological Sciences 10(3): 247-250.

Omori, M. 1978. Zooplankton fisheries of the world: a review. Marine Biology 48(3): 199-205.

Omori, M. 1975. The Systematics, Biogeography, and Fishery of Epipelagic Shrimps of the Genus Acetes (Crustacea, Decapoda, Sergestidae). Tokyo, Japan: Ocean Research Institute, University of Tokyo.

Page, R.D.M. 1996. Tree view: An application to display phylogenetic trees on personal computers. Computer Applications in the Biosciences 12(4): 357-358.

Pathansali,D. 1966. Acetes (Sergestidae) from Malay Peninsula. Bulletin of the National Museum Singapore 33(8): 59-63.

Pellerito, R., Arculeo, M. \& Bonhomme, F. 2009. Recent expansion of Northeast Atlantic and Mediterranean populations of Melicertus (Penaeus) kerathurus (Crustacea: Decapoda). Fisheries Science 75(5): 1089-1095.

Pfeiler, E., Hurtado, L.A., Knowles, L.L., Torre-Cosío, J., Bourillón-Moreno, L., Márquez-Farías, J.F. \& MontemayorLpoez, G. 2005. Population genetics of the swimming crab Callinectes bellicosus (Brachyura: Portunidae) from the eastern Pacific Ocean. Marine Biology 146(3): 559-569.

Pfenninger, M. \& Schwenk, K. 2007. Cryptic animal species are homogenously distributed among taxa and biogeographical regions. BMC Evolutionary Biology 7: 121-126.

Pillians, B., Chappell, J. \& Naish, T.R. 1998. A review of the Milankovitch climatic beat: Template for Plio-Pleistocene sea-level changes and sequence statigraphy. Sedimentary Geology 122(1-4): 5-21.

Posada, D. 2009. Selection of models of DNA evolution with jModelTest. In Bioinformatic Analysis of DNA Sequences, edited by Posada, D. New Jersey: Human Press. pp. 93-112.

Posada, D. 2008. jModelTest: Phylogenetic model averaging. Molecular Biology and Evolution 25(7): 1253-1256. 
Quan, J., Zhuang, Z., Deng, J., Dai, J. \& Zhang, Y.P. 2004. Phylogenetic relationships of 12 Penaeoidea shrimp species deduced from mitochondrial DNA sequences. Biochemical Genetics 42(9): 331-345.

Ramos-Onsins, S.E. \& Rozas, J. 2002. Statistical properties of new neutrality tests against population growth. Molecular Biology and Evolution 19(12): 2092-2100.

Rand, D.M. 1996. Neutrality tests of molecular markers and connection between DNA polymorphism, demography, and conservation biology. Conservation Biology 10(2): 665-671.

Rogers, A.R. 1995. Genetic evidence for a Pleistocene population explosion. Evolution 49(4): 608-615.

Rogers, A.R. \& Harpending, H.C. 1992. Population growth makes waves in the distribution of pairwise genetic differences. Molecular Biology and Evolution 9: 552-569.

Roldán, M.I., Heras, S., Patellani, R. \& Maltagliati, F. 2009. Analysis of genetic structure of red shrimp Aristeus antennatus from the Western Mediterranean employing two mitochondrial regions. Genetica 136(1): 1-4.

Ronquist, F. \& Huelsenbeck, J.P. 2003. MrBayes 3: Bayesian phylogenetic inference under mixed models. Bioinformatics 19(12): 1572-1574.

Saiki, R., Gelfand, D., Stoffel, S., Scharf, S., Higuchi, R., Horn, G.T., Mullis, K.B. \& Erlich, H.A. 1988. Primer-directed enzymatic amplification of DNA with a thermostable DNA polymerase. Science 239(4839): 487-491.

Saitou, N. \& Nei, M. 1987. The neighbor-joining method: A new method for reconstructing phylogenetic trees. Molecular Biology and Evolution 4(4): 406-425.

Schneider, S. \& Excoffier, L. 1999. Estimation of past demographic parameters from the distribution of pairwise differences when mutation rates vary among sites: Application to human mitochondrial DNA. Genetics 152(3): 1079-1089.

Slatkin, M. \& Hudson, R.R. 1991. Pairwise comparison of mitochondrial DNA sequences in stable and exponentially growing populations. Genetics 129(2): 555-562.

Song, H., Buhay, J.E., Whiting, M.F. \& Crandall, K.A. 2008. Many species in one: DNA barcoding overestimates the number of species when nuclear mitochondrial pseudogenes are coamplified. Proceedings of the National Academy of Sciences of the United States of America 105(36): 1348613491.

Stockley, B., Menezes, G., Pinho, M.R. \& Rogers, A.D. 2005. Genetic population structure in the black-spot sea bream (Pagellus bogaraveo Brúnnich, 1768) from the NE Atlantic. Marine Biology 146(4): 793-804.

Sugiura, N. 1978. Further analysts of the data by Akaike's information criterion and the finite corrections. Communications in Statistics, Theory and Methods A7(1): 13-26.

Swofford, D. 2002. PAUP*. Phylogenetic Analysis using Parsimony (*and other methods). Version 4. Massachusetts: Sinauer Associates.

Tajima,F. 1989. Statistical method for testing the neutral mutation hypothesis by DNA polymorphism. Genetics 123: 585-595.

Tamura, K., Dudley, J., Nei, M. \& Kumar, S. 2007. MEGA4: Molecular Evolutionary Genetics Analysis (MEGA) Software Version 4.0. Molecular Biology and Evolution 24(8): 15961599.

Templeton, A.R., Crandall, K.A. \& Sing, C.F. 1992. A cladistic analysis of phenotypic associations with haplotypes inferred from restriction endonuclease mapping and DNA sequence data. III. Cladogram estimation. Genetics 132(2): 619-633.
Thorpe, J.P., Solé-Cava, A.M. \& Watts, P.C. 2000. Exploited marine invertebrates: Genetics and fisheries. Hydrobiologia 420(1): 165-184.

Tong, J.G., Chan, T.Y. \& Chu, K.H. 2000. A preliminary phylogenetic analysis of Metapenaeopsis (Decapoda: Penaeidae) based on mitochondrial DNA sequences of selected species from the Indo-West Pacific. Journal of Crustacean Biology 20(3): 541-549.

Trontelj, P., Machino, Y. \& Sket, B. 2005. Phylogenetic and phylogeographic relationships in the crayfish genus Austropotamobius inferred from mitochondrial COI gene sequences. Molecular Phylogenetics and Evolution 34(1): 212-226.

Tsoi, K.H., Chan, T.Y. \& Chu, K.H. 2007. Molecular population structure of the kuruma shrimp Penaeus japonicus species complex in western Pacific. Marine Biology 150(6): 13451364.

Tsoi, K.H., Wang, Z.Y. \& Chu, K.H. 2005. Genetic divergence between two morphologically similar varieties of the kuruma shrimp Penaeus japonicus. Marine Biology 147(2): 367-379.

Voris, H.K. 2000. Maps of Pleistocene sea levels in Southeast Asia: Shorelines, river systems and time durations. Journal of Biogeography 27: 1153-1167.

Ward, R.D. 2000. Genetics in fisheries management. Hydrobiologia 420(1): 191-201.

Ward, R.D.\& Grewe, P.M. 1994. Appraisal of molecular genetic techniques in fisheries. Reviews in Fish Biology and Fisheries 4(3): 300-325.

Weir, B.S.\& Cockerham, C. 1984. Estimating F - statistics for the analysis of population structure. Evolution 38(6): 1358-1370.

Williams, S.T. \& Knowlton, N. 2001 . Mitochondrial pseudogenes are pervasive and often insidious in the snapping shrimp genus Alpheus. Molecular Biology and Evolution 18(8): 1484-1493.

Williams, S.T., Jara, J., Gomez, E. \& Knowlton, N. 2002. The marine Indo-West Pacific break: Contrasting the resolving power of mitochondrial and nuclear genes. Integrative and Comparative Biology 42(5): 941-952.

Williams, S.T., Knowlton, N., Weigt, L.A. \& Jara, J.A. 2001 Evidence for three major clades within the snapping shrimp genus Alpheus inferred from nuclear and mitochondrial gene sequence data. Molecular Phylogenetics and Evolution 20(3): 375-389.

Wong, B.Y. 2013. Genetic diversity and morphometric characterization of Acetes (Decapoda: Sergestidae) collected from the west coast of Peninsular Malaysia. Master of Science dissertation, Universiti Tunku Abdul Rahman, Malaysia (Unpublished). (http://eprints.utar.edu.my/802/).

Wong, B.Y., Ong, H.K.A. \& Khoo, G. 2015. Length-weight relationships of Acetes spp. sampled along the west coast of Peninsular Malaysia. Sains Malaysiana 44(3): 379-386.

Xiao, Y. \& Greenwood, J.G. 1993. The biology of Acetes (Crustacea: Sergestidae). In Oceanography and Marine Biology: An Annual Review, Vol. 31, edited by Ansell, A.D., Gibson, R.N. \& Barnes, M. London: UCL Press.

Zhang, D.X. \& Hewitt, G.M. 1996. Nuclear integrations: Challenges for mitochondrial DNA markers. Trends in Ecology and Evolution 11(6): 247-251.

Zitari-Chatti, R., Chatti, N., Fulgione, D., Caiazza, I., Aprea, G., Elouaer, A., Said, K. \& Capriglione, T. 2009. Mitochondrial DNA variation in the caramote prawn Penaeus (Melicertus) kerathurus across a transition zone in the Mediterranean Sea. Genetica 136(3): 439-447. 
Boon Yee Wong

Faculty of Engineering and Science

Universiti Tunku Abdul Rahman

Jalan Genting Klang, Setapak

53300 Kuala Lumpur, Federal Territory

Malaysia

Taranjeet Kaur Awtar Singh \& Gideon Khoo

Faculty of Science

Universiti Tunku Abdul Rahman

Jalan Universiti, Bandar Barat

31900 Kampar, Perak Darul Ridzuan

Malaysia

\section{Han Kiat Alan Ong*}

Department of Pre-clinical Sciences

Faculty of Medicine and Health Sciences

Universiti Tunku Abdul Rahman

Jalan Sungai Long, Bandar Sungai Long, Cheras

43000 Kajang, Selangor Darul Ehsan

Malaysia

*Corresponding author; email: onghk@utar.edu.my

Received: 5 November 2016

Accepted: 31 May 2017 